\title{
Patent Literature on Mosquito Repellent Inventions which Contain Plant Essential Oils - A Review
}

Authors

Affiliations
Adrian Martin Pohlit ${ }^{1,3}$, Norberto Peporine Lopes ${ }^{3}$, Renata Antonaci Gama ${ }^{4}$, Wanderli Pedro Tadei ${ }^{2}$, Valter Ferreira de Andrade Neto ${ }^{4}$

${ }^{1}$ Natural Products Department, National Institute for Amazon Research, Manaus, Brazil

${ }^{2}$ Health Sciences Department, National Institute for Amazon Research, Manaus, Brazil

${ }^{3}$ Department of Chemistry and Physics, College of Pharmaceutical Sciences, São Paulo University, Ribeirão Preto, Brazil

${ }^{4}$ Department of Microbiology and Parasitology, Rio Grande do Norte Federal University, Natal, Brazil

\section{Key words \\ - botanical repellents \\ - natural products \\ plant-based repellents \\ - repellent essential oils \\ - mosquito repellents}

received July 2,2010

revised Dec. 28, 2010

accepted January 3, 2011

\section{Bibliography}

Dol http://dx.doi.org/

10.1055/s-0030-1270723

Published online February 15, 2011

Planta Med 2011; 77: 598-617

(c) Georg Thieme Verlag KG

Stuttgart - New York .

ISSN 0032-0943

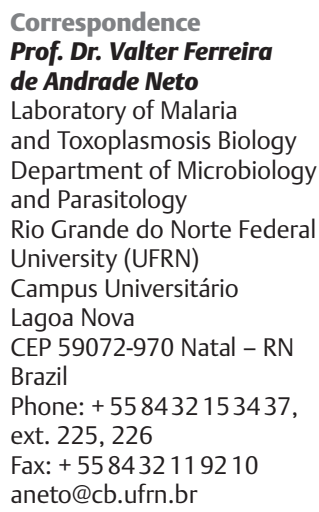

\section{Abstract}

$\nabla$

Bites of mosquitoes belonging to the genera Anopheles Meigen, Aedes Meigen, Culex L. and Haemagogus L. are a general nuisance and are responsible for the transmission of important tropical diseases such as malaria, hemorrhagic dengue and yellow fevers and filariasis (elephantiasis). Plants are traditional sources of mosquito repelling essential oils (EOs), glyceridic oils and repellent and synergistic chemicals. A Chemical Abstracts search on mosquito repellent inventions containing plant-derived EOs revealed 144 active patents mostly from Asia. Chinese, Japanese and Korean language patents and those of India (in English) accounted for roughly 3/4 of all patents. Since 1998 patents on EO-containing mosquito repellent inventions have almost doubled about every 4 years. In general, these patents describe repellent compositions for use in topical agents, cosmetic products, incense, fumigants, indoor and outdoor sprays, fibers, textiles among other applications. 67 EOs and 9 glyceridic oils were individually cited in at least 2 patents. Over $1 / 2$ of all patents named just one EO. Citronella [Cymbopogon nardus (L.) Rendle, C.winterianus Jowitt ex Bor] and eucalyptus (Eucalyptus L'Hér. spp.) EOs

\section{Introduction}

$\nabla$

\section{Mosquito vectors of severe}

\section{tropical diseases}

Severe human tropical diseases such as malaria, dengue and yellow fevers and filariasis are transmitted by the bites of infected hematophagous female mosquitoes belonging to the genera Aedes Meigen, Anopheles Meigen, Culex L. and Haemagogus L. (Diptera: Culicidae). For example, about 3.3 billion people $-1 / 2$ of the world's population are at risk of contracting malaria. In 2008, there were more than 247 million cases and more than were each cited in approximately $1 / 3$ of all patents. Camphor [Cinnamomum camphora (L.) J. Presl], cinnamon (Cinnamomum zeylanicum Blume), clove [Syzygium aromaticum (L.) Merr. \& L.M. Perry], geranium (Pelargonium graveolens L'Hér.), lavender (Lavandula angustifolia Mill.), lemon [Citrus $\times$ limon (L.) Osbeck], lemongrass [Cymbopogon citratus (DC.) Stapf] and peppermint (Mentha $\times$ piperita L.) EOs were each cited in $>10 \%$ of patents. Repellent chemicals present in EO compositions or added as pure "natural" ingredients such as geraniol, limonene, p-menthane-3,8-diol, nepetalactone and vanillin were described in approximately $40 \%$ of all patents. About $25 \%$ of EO-containing inventions included or were made to be used with synthetic insect control agents having mosquito repellent properties such as pyrethroids, $N, N$-diethyl- $m$-toluamide (DEET), ( \pm )-p-menthane-3,8-diol (PMD) and dialkyl phthalates. Synergistic effects involving one or more EOs and synthetic and/or natural components were claimed in about $10 \%$ of all patents. Scientific literature sources provide evidence for the mosquito repellency of many of the EOs and individual chemical components found in EOs used in patented repellent inventions. 
50 million people contract the disease per year. Around 500000 dengue patients, most of whom are children, require hospitalization each year and around $2.5 \%$ of those affected die [2]. Another serious tropical disease which threatens about 1 billion people in 80 countries is filariasis or elephantiasis. This disease already affects an estimated 120 million people and severely incapacitates and deforms 40 million people worldwide. Filariasis is caused by infections by several roundworm species of which Wuchereria bancrofti Cobbold (Filariidea: Onchocercidae) is the most important and is transmitted by the bites of the common house mosquito $C x$. pipiens L. complex, $C x$. quinquefaciatus Say, Aedes and Anopheles spp. [3,4]. Yellow fever is an arbovirus of the Flavivirus genus (Flaviviridae) which is transmitted from monkeys in the jungle to humans and then from human to human by mosquitoes. The most significant yellow fever mosquito vector is Ae. aegypti. Despite the existence of effective vaccines, there are an estimated 200000 cases of yellow fever and approximately 30000 deaths attributed to this disease each year [5]. In public health initiatives which aim to limit or eradicate these and other tropical diseases, mosquito vector control methods such as repellence figure prominently among those which are employed.

Synthetic mosquito repellents DEET and alkyl phthalates For more than 50 years, the synthetic compound DEET ( $N, N$-diethyl-m-toluamide), has been the most effective single repellent for mosquito species and is the basis for many commercial repellent products on the market. Despite reports of severe toxic properties which can dramatically affect adults and especially young children including dermatitis, allergic reactions, neurological (seizures, coma) and cardiovascular toxicity, the risk of serious toxic effects from DEET is considered slight. Nevertheless, DEET should always be used at the lowest effective dose possible. Also, dimethyl and di- $n$-butyl phthalates (DMP and DBP, respectively), which are effective mosquito repellents and were widely used in the last century, are no longer generally recommended for use as mosquito repellents due to their toxicity [6].

\section{Plants as sources of mosquito control agents}

Plants have historically been valuable sources of agents for the control of insects $[3,7]$. They are the sources of the natural insecticidal and larvicidal substances nicotine (Nicotiana L. spp.), quassin (Quassia amara L.), rotenone and rotenoids (Derris Lour. spp. and Lonchocarpus Kunth spp. roots), pyrethrins like chrysanthamic acid and its derivatives present in pyrethrum [extracts of Chrysanthemum cinerariifolium (Trevir.) Vis. flowers] and azadirachtin (Azadirachta indica A. Juss. seed kernel). These and other natural insect control agents have served as the basis for the development of the structurally-related synthetic pyrethroid, nicotinoid and rotenoid classes of insecticides and piperonyl butoxide synergist. Also, pyrethroids and piperonyl butoxide synergism are the basis for a number of commercially available mosquito control products in use today [3].

\section{Botanical repellents}

Citronella essential oils (EOs) are obtained mainly from varieties of Cymbopogon nardus (L.) Rendle (Ceylon citronella) and C. winterianus Jowitt ex Bor (Java citronella). They have been used in mosquito repellency for more than a century in much of the world and are the most widely used natural repellents today [3]. Also, EOs of Eucalyptus L'Hér. spp. are widely used to repel insects, including mosquitoes, and contain insecticidal and repellent components $p$-menthane-3,8-diol (PMD), 1,8-cineole, $\alpha$ - pinene, $p$-cymene and $\gamma$-terpinene among other active compounds [8]. According to a recent review of the scientific literature, the most frequently studied repellent EOs are those obtained from species belonging to the genera Cymbopogon Spreng., Ocimum L. and Eucalyptus L'Hér. spp. and a number of mosquito repellent EOs have been identified in recent years having known active repellent chemical components [7]. Mosquito repellency is believed to be due to the synergistic interactions of the chemical components in EOs. Furthermore, strong synergistic effects between EOs and isolated natural or synthetic substances have been reported [7].

The United States Environmental Protection Agency [9] has registered citronella EO, eucalyptus EO and other plant oils as safe and effective ingredients for use in topical insect repellents. However, caution is recommended in the use of EOs in general due to a number of potential toxic effects [7]. Among the important toxic effects of EOs are mutagenicity and genotoxicity. Another toxic effect is the allergenicity of EO chemical components which are controlled in the European Community and elsewhere. Interestingly, a number of repellent and insecticidal plant EOs and their chemical constituents have been evaluated using a variety of methods and are believed to be non-mutagenic [10].

A number of commercial repellent products have been developed over the past decades which utilize derivatives of plants such as EOs, fractions and their isolated chemical components and synthetic components. Thus, it is important to have a comprehensive knowledge of the commercially significant uses of EOs in mosquito repellent inventions and to the best of our knowledge the patent literature on this topic has not been reviewed. The aim of the present review is to explore and analyze patent literature on mosquito repellent inventions which make use of or are based wholly on plant EOs and/or their chemical components. A secondary aim is to analyze the scientific bases and relevancy of the use of plant EOs and chemical components of these oils in patented mosquito repellent formulations.

\section{Chemical Abstracts Search Criteria}

\section{$\nabla$}

A Chemical Abstracts search of the patent literature for the period of 1991 through May, 2010 was performed using SciFinder Schol$\operatorname{ar}^{\circledR}$ [11]. Combinations of the key words "repellent", "mosquito" and "essential oil" generated an initial set of approximately 160 patents. This set was further refined. Patents describing mosquitocidal/larvicidal inventions, but having no stated claim or use as mosquito repellents were eliminated. Also, patented mosquito repellent inventions which did not make use of at least one commercially-obtained, plant-derived oil [a volatile (essential) oil, a concrete, or a pressed oil] or which did not describe the preparation of an EO by physical means for use within the patent were eliminated. This approach eliminated patents presenting solvent extraction performed on mixtures of several plant materials followed, for example, by distillation and evaporation as a means of obtaining the mosquito repellent invention. Also, by this criterion, incense and other smoke-generating inventions made from mosquito repellent plants but having no (added) EO in the composition were eliminated. Applying the above criteria led to a data set of 144 patents describing plant oil-containing mosquito repellent inventions which was the basis for the analysis presented below. 


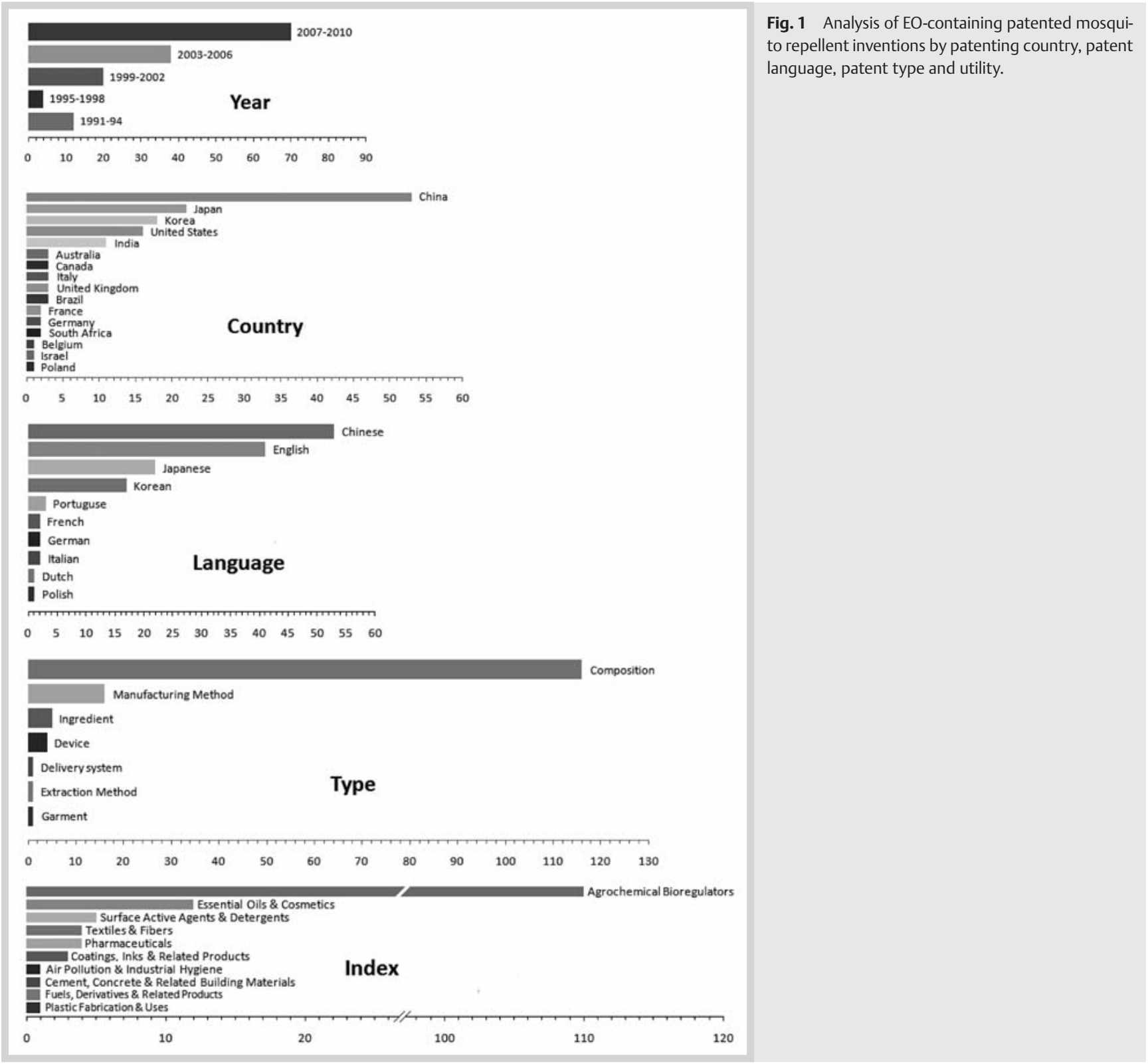

\section{Patenting Countries and Patent Families: Trends \\ $\nabla$}

The contribution of China, Japan, Korea and India to the overall number of patented EO-containing mosquito repellent inventions is significant. These countries accounted for, respectively, $37,15,13$ and $8 \%(73 \%$ ) of all patents ( Fig. 1). An interesting trend is that all 53 Chinese, 17 of 18 Korean, 20 of 22 Japanese and 9 of 11 Indian patents have only been deposited in their countries of origin and in general have not been followed-up by later patents. Also, all Belgian, Brazilian, German and Polish patents followed the rule of single deposits without follow-up patents. In contrast, industrial, academic and other patents originating in Australia, Canada, the United Kingdom and the United States gave rise to larger patent families, made greater use of the World Patent System and led to deposits of patents on EO-containing repellents in multiple countries as a rule. Finally, more than $75 \%$ of all patented repellent inventions are indexed as agrochemical bioregulators and over $80 \%$ describe chemical compositions (often together with preparation details) ( $\bullet$ Fig. 1).

\section{EOs Used in Patented Mosquito Repellent Inventions $\nabla$}

Plant taxonomic information [12], extraction methods, chemical composition, literature sources $[8,10,13-115]$ and frequency of use for 67 EOs and 9 glyceridic oils which were individually cited in at least $2(1.4 \%)$ of the total number of patents are presented in - Table 1. Approximately $60 \%$ of all patents named just one plant EO. One patent claimed to use up to 44 plant oils in formulations. Citronella (34.7\%) and eucalyptus (30.6\%) EOs were each named in about $1 / 3$ of all patented repellent inventions followed by (species, \% of patents): lavender (Lavandula angustifolia Mill., 21.5\%), peppermint (Mentha $\times$ piperita L., 16.7\%), clove [Syzygium aromaticum (L.) Merr. \& L. M. Perry, 15.3\%], lemongrass [Cymbopogon citratus (DC.) Stapf, 14.6\%], cinnamon (Cinnamomum zeylanicum Blume, 12.5\%), geranium (Pelargonium graveolens L'Hér., 11.8\%), camphor [Cinnamomum camphora (L.) J. Presl, 11.1\%] and lemon [Citrus $\times$ limon (L.) Osbeck, 11.1\%] EOs.

A number of EOs were cited in only one patented repellent invention (and were not included in $\odot$ Table 1). Given the importance 
Table 1 Botanic information, extraction methods, major chemical components, literature sources and frequency (\%) of use of plant essential and glyceridic oils in patented mosquito repellent inventions, 1991 - May, 2010.

\begin{tabular}{|c|c|c|c|c|c|c|c|}
\hline Oil & Species & Family & Part & Method & Major components & Lit. & $\%$ Patents \\
\hline \multicolumn{8}{|c|}{ Essential Oils } \\
\hline Ambrette & $\begin{array}{l}\text { Abelmoschus } \\
\text { moschatus Medik. }\end{array}$ & Malvaceae & $\begin{array}{l}\text { whole } \\
\text { seed }\end{array}$ & steam distilled & $\begin{array}{l}\text { 2E,6E-farnesyl acetate, Z-7-hexadecen-16-olide, } \\
\beta \text {-farnesene }\end{array}$ & {$[13,14]$} & 1.4 \\
\hline Angelica & Angelica archangelica L. & Apiaceae & root & steam distilled & $\begin{array}{l}\text { ligustilide, } \boldsymbol{\alpha} \& \boldsymbol{\beta} \text {-pinene, carvacrol, 3-carene, } \\
\text { limonene, } \beta \text {-phellandrene, } 15 \text {-pentadecanolide }\end{array}$ & {$[15,16]$} & 1.4 \\
\hline Anise & Pimpinella anisum L. & Apiaceae & fruit, seed & steam distilled & trans-anethole & [17] & 4.2 \\
\hline Artemisia & $\begin{array}{l}\text { Artemisia argyi H. Lév. } \\
\text { \& Vaniot }\end{array}$ & Asteraceae & leaf & steam distilled & $\begin{array}{l}\text { germacrene } \mathrm{D}, \alpha \text {-phellandrene, } \alpha \text {-myrcene, } \\
\text { 1,8-cineole, borneol, terpinol, spathulenol }\end{array}$ & {$[18,19]$} & 4.9 \\
\hline Basil & Ocimum basilicum L. & Lamiaceae & $\begin{array}{l}\text { leaf, } \\
\text { flower top }\end{array}$ & steam distilled & $\begin{array}{l}\text { estragole, limonene, fenchone, linalool, } \\
\text { eugenol } E \text {-methyl cinnamate, 1,8-cineole }\end{array}$ & {$[20-22]$} & 4.9 \\
\hline Bay laurel & Laurus nobilis L. & Lauraceae & leaf & steam distilled & $\begin{array}{l}\text { 1,8-cineole, sabinene, } \alpha \text {-terpinyl acetate, } \\
\text { linalool }\end{array}$ & {$[23,24]$} & 1.4 \\
\hline Bergamot & $\begin{array}{l}\text { Citrus } \times \text { bergamia } \\
\text { Risso }\end{array}$ & Rutaceae & $\begin{array}{l}\text { fresh or } \\
\text { dried peel }\end{array}$ & pressed & $\begin{array}{l}\text { limonene, linalyl acetate, } \boldsymbol{\beta} \text {-pinene, } \\
\boldsymbol{\gamma} \text {-terpinene, linalool }\end{array}$ & [24] & 1.4 \\
\hline Camphor & $\begin{array}{l}\text { Cinnamomum } \\
\text { camphora (L.) J. Presl }\end{array}$ & Lauraceae & $\begin{array}{l}\text { wood, bark, } \\
\text { leaf }\end{array}$ & steam distilled & $\begin{array}{l}\text { 1,8-cineole, } \alpha \text {-terpineol, } \alpha \text {-pinene, linalool, } \\
\text { camphor, sabinene }\end{array}$ & [10] & 11.1 \\
\hline Cassia & $\begin{array}{l}\text { Cinnamomum cassia } \\
\text { (L.) C. Presl }\end{array}$ & Lauraceae & $\begin{array}{l}\text { leaf, bark, } \\
\text { stalk }\end{array}$ & steam distilled & $\begin{array}{l}\text { bark: E-cinnamaldehyde, methyl o-salicylate; } \\
\text { leaf: 3-methoxy-1,2-propanediol, } \\
\text { E-cinnamaldehyde, o-methoxy- } \\
\text { cinnamaldehyde }\end{array}$ & {$[25,26]$} & 2.1 \\
\hline $\begin{array}{l}\text { Catnip, } \\
\text { catmint }\end{array}$ & Nepeta cataria L. & Lamiaceae & $\begin{array}{l}\text { dry leaf, } \\
\text { stem }\end{array}$ & steam distilled & $\begin{array}{l}\text { nepetalactone, 1,8-cineole, } \alpha \text {-humulene, } \\
\alpha \text {-pinene, } E \text {-geraniol, } \beta \text {-caryophyllene, } \\
\text { citronellol }\end{array}$ & {$[20,27,28]$} & 4.9 \\
\hline Cedar & $\begin{array}{l}\text { Cedrus Trew } \\
\text { (Cupressus L., } \\
\text { Juniperus L.) spp. }\end{array}$ & $\begin{array}{l}\text { Pinaceae } \\
\text { (Cupressaceae) }\end{array}$ & wood & steam distilled & $\begin{array}{l}\text { thujopsene, eudesmol, E-(+)- } \alpha \text {-atlantone; } \\
\alpha, \beta \text { \&-himachalenes; } \alpha \text { - \& } \beta \text {-cedrenes; } \\
\text { limonene, } \beta \text {-phellandrene, } \boldsymbol{\alpha} \& \boldsymbol{\beta} \text {-pinene, } \\
\text { 3-carene; } p \text {-methyl- } \Delta \text {-3-tetrahydro \& } p \text {-methyl } \\
\text { acetophenones; hinokitiol, carvacrol }\end{array}$ & [29] & 9.7 \\
\hline Chamomile & $\begin{array}{l}\text { Chamaemelum } \\
\text { nobile (L.) All. } \\
\text { Matricaria recutita L. }\end{array}$ & Asteraceae & $\begin{array}{l}\text { seed, leaf, } \\
\text { flower }\end{array}$ & steam distilled & $\begin{array}{l}\text { Roman: isobutyl, isoamyl \& 2-methylpentyl } \\
\text { angelates, } \alpha \text {-pinene } \\
\text { German: } E-\beta \text {-farnesene, E,E- } \alpha \text {-farnesene, } \\
\alpha \text {-bisabolol, } \alpha \text {-bisabolol oxides A \& B }\end{array}$ & $\begin{array}{l}{[20,28,} \\
30]\end{array}$ & 2.1 \\
\hline $\begin{array}{l}\text { Chrysan- } \\
\text { themum }\end{array}$ & $\begin{array}{l}\text { Chrysanthemum } \\
\text { indicum L. }\end{array}$ & Asteraceae & dry flower & steam distilled & $\begin{array}{l}\text { verbenol, 2-(2,4-hexadiynylidene)-1,6- } \\
\text { dioxaspiro[4.4]non-3-ene, 1,8-cineole, } \\
\alpha \text {-pinene, camphor, borneol, bornyl acetate }\end{array}$ & {$[31,32]$} & 2.8 \\
\hline Cinnamon & $\begin{array}{l}\text { Cinnamomum } \\
\text { zeylanicum Blume }\end{array}$ & Lauraceae & bark, leaf & steam distilled & eugenol, cinnamaldehyde & {$[25,33,34]$} & 12.5 \\
\hline Citronella & $\begin{array}{l}\text { Cymbopogon nardus } \\
\text { (L.) Rendle, } \\
\text { C. winterianus } \\
\text { Jowitt ex Bor }\end{array}$ & Poaceae & leaf & steam distilled & $\begin{array}{l}\text { citronellal, geraniol, citronellol, geranyl } \\
\text { acetate }\end{array}$ & {$[35,36]$} & 34.7 \\
\hline Citrus & $\begin{array}{l}\text { Citrus } \times \text { limon (L.) } \\
\text { Osbeck, C. } \times \text { sinen- } \\
\text { sis }(\text { L.) Osbeck, } \\
\text { C. } \times \text { aurantifolia L. }\end{array}$ & Rutaceae & peel & $\begin{array}{l}\text { pressed, steam } \\
\text { distilled }\end{array}$ & see orange, lemon, lime oil compositions & - & 1.4 \\
\hline Clove & $\begin{array}{l}\text { Syzygium aromaticum } \\
\text { (L.) Merr. \& L. M. Perry }\end{array}$ & Myrtaceae & $\begin{array}{l}\text { flower } \\
\text { bud }\end{array}$ & steam distilled & eugenol, caryophyllene, eugenyl acetate & [37] & 15.3 \\
\hline Coriander & $\begin{array}{l}\text { Coriandrum } \\
\text { sativum L. }\end{array}$ & Apiaceae & $\begin{array}{l}\text { fruit, } \\
\text { seed }\end{array}$ & steam distilled & $\begin{array}{l}\text { linalool, geraniol, geranyl acetate, } \\
\text { 2-decenal, 3-dodecenal }\end{array}$ & $\begin{array}{l}{[20,38,} \\
39]\end{array}$ & 2.1 \\
\hline Cypress & $\begin{array}{l}\text { Cupressus } \\
\text { sempervirens L. }\end{array}$ & Cupressaceae & $\begin{array}{l}\text { needle, } \\
\text { twig }\end{array}$ & steam distilled & $\begin{array}{l}\text { sabinene, } \boldsymbol{\alpha} \text {-pinene, terpinen-4-ol, } \\
\text { limonene }\end{array}$ & {$[40,41]$} & 4.2 \\
\hline Dill & $\begin{array}{l}\text { Anethum } \\
\text { graveolens L. }\end{array}$ & Apiaceae & $\begin{array}{l}\text { seed, leaf, } \\
\text { stem }\end{array}$ & steam distilled & $\begin{array}{l}\text { carvone, limonene, } \alpha \text {-phellandrene, } \\
\alpha \text {-pinene, cis-dihydrocarvone }\end{array}$ & {$[42,43]$} & 1.4 \\
\hline Eucalyptus & Eucalyptus L’Hér. spp. & Myrtaceae & leaf & steam distilled & $\begin{array}{l}\text { 1,8-cineole, } p \text {-menthane-3,8-diol, } \\
\alpha \text {-pinene, } p \text {-cymene, } \gamma \text {-terpinene, } \\
\text { eucamalol, allo-ocimene, citronellol, } \\
\alpha \text {-terpineol }\end{array}$ & [8] & 30.6 \\
\hline Fennel & Foeniculum vulgare Mill. & Apiaceae & fruit & steam distilled & $\begin{array}{l}\text { E-anethole, }(+) \text {-fenchone, } \alpha \text {-phellandrene, } \\
( \pm) \text {-limonene, estragole }\end{array}$ & [24] & 4.9 \\
\hline Garlic & Allium sativum L. & Amaryllidaceae & bulb & steam distilled & $\begin{array}{l}\text { diallyl disulfide, diallyl trisulfide, methyl allyl } \\
\text { trisulfide }\end{array}$ & {$[44,45]$} & 6.3 \\
\hline Geranium & $\begin{array}{l}\text { Pelargonium graveolens } \\
\text { L'Hér. }\end{array}$ & Geraniaceae & $\begin{array}{l}\text { leaf, } \\
\text { stem }\end{array}$ & steam distilled & $\begin{array}{l}\text { 2-phenylethanol, geraniol, citronellol, } \\
\text { geranyl acetate }\end{array}$ & [46] & 11.8 \\
\hline
\end{tabular}


Table 1 Botanic information, extraction methods, major chemical components, literature sources and frequency (\%) of use of plant essential and glyceridic oils in patented mosquito repellent inventions, 1991 - May, 2010. (continued)

\begin{tabular}{|c|c|c|c|c|c|c|c|}
\hline Oil & Species & Family & Part & Method & Major components & Lit. & \% Patents \\
\hline \multicolumn{8}{|l|}{ Essential Oils } \\
\hline Ginger & $\begin{array}{l}\text { Zingiber officinale } \\
\text { Roscoe }\end{array}$ & Zingiberaceae & rhizome & steam distilled & $\begin{array}{l}\text { geranial, } \alpha \text {-zingiberene, } E, E-\alpha \text {-farnesene, } \\
\text { neral, ar-curcumene, geraniol }\end{array}$ & {$[47,48]$} & 1.4 \\
\hline Grapefruit & Citrus reticulata Blanco & Rutaceae & peel & pressed & limonene, geranial, neral & [49] & 2.1 \\
\hline $\begin{array}{l}\text { Guaiac } \\
\text { wood }\end{array}$ & $\begin{array}{l}\text { Bulnesia sarmientoi } \\
\text { Lorentz ex Griseb. }\end{array}$ & Zygophyllaceae & wood & steam distilled & bulnesol, guaiol, $\alpha$-bulnesene & [50] & 1.4 \\
\hline Hiba & $\begin{array}{l}\text { Thujopsis dolabrata } \\
\text { (Thunb. ex L.f.) } \\
\text { Siebold \& Zucc. }\end{array}$ & Cupressaceae & wood & steam distilled & $\begin{array}{l}\text { sabinene, 4-terpineol, thujopsene, } \\
\text { hinokitiol, } \alpha \text {-thujaplicine, carvacrol }\end{array}$ & {$[51-53]$} & 2.1 \\
\hline Ho leaf & $\begin{array}{l}\text { Cinnamomum } \\
\text { camphora (L.) J. Presl }\end{array}$ & Lauraceae & leaf & steam distilled & $\begin{array}{l}\text { 1,8-cineole, } \alpha \text {-terpineol, linalool, } \\
\text { camphor, safrole, sabinene, nerolidol }\end{array}$ & {$[10,54,55]$} & 1.4 \\
\hline Hyssop & Hyssopus officinalis L. & Lamiaceae & $\begin{array}{l}\text { leaf, } \\
\text { flower }\end{array}$ & steam distilled & $\begin{array}{l}\text { sabinene, pinocamphene, isopinocamphene, } \\
\text { isopinocamphone, pinocarvone, cis \& } \\
\text { trans-pinocamphones, } \boldsymbol{\beta} \text {-pinene, 1,8-cineole, } \\
\text { camphor, linalool }\end{array}$ & {$[56-58]$} & 1.4 \\
\hline Jasmine & Jasminum officinale L. & Oleaceae & flower & solvent extracted & $\begin{array}{l}\text { linalool, benzyl acetate, methyl \& benzyl } \\
\text { benzoates, methyl anthranilate, Z-jasmone, } \\
\text { eugenol }\end{array}$ & {$[59,60]$} & 3.5 \\
\hline Juniper & $\begin{array}{l}\text { Juniperus } \\
\text { communis L. }\end{array}$ & Cupressaceae & fruit & steam distilled & $\begin{array}{l}\alpha \text {-pinene, myrcene, sabinene, } \\
\text { germacrene } D\end{array}$ & [61] & 1.4 \\
\hline $\begin{array}{l}\text { Lady-of- } \\
\text { the-night }\end{array}$ & Cestrum nocturnum $\mathrm{L}$. & Solanaceae & flower & $\begin{array}{l}\text { solvent extracted, } \\
\text { steam distilled }\end{array}$ & phenylethyl alcohol, benzyl alcohol, eugenol & [62] & 2.1 \\
\hline Lavender & $\begin{array}{l}\text { Lavandula angustifolia } \\
\text { Mill. }\end{array}$ & Lamiaceae & flower & steam distilled & $\begin{array}{l}\text { linalool, linalyl acetate, lavandulyl acetate, } \\
\alpha \text {-terpineol, geranyl acetate, terpinen-4-ol, } \\
\text { 1,8-cineole }\end{array}$ & {$[63,64]$} & 21.5 \\
\hline Lemon & $\begin{array}{l}\text { Citrus } \times \text { limon (L.) } \\
\text { Osbeck }\end{array}$ & Rutaceae & peel & pressed & limonene, $\beta$-pinene, $\gamma$-terpinene & [65] & 11.1 \\
\hline $\begin{array}{l}\text { Lemon } \\
\text { eucalyptus }\end{array}$ & $\begin{array}{l}\text { Eucalyptus citriodora } \\
\text { Hook. }\end{array}$ & Myrtaceae & leaf, twig & steam distilled & citronellal, citronellol & {$[8,66]$} & 8.3 \\
\hline Lemongrass & $\begin{array}{l}\text { Cymbopogon } \\
\text { citratus (DC.) Stapf }\end{array}$ & Poaceae & leaf & steam distilled & geranial, neral, myrcene & [41] & 14.6 \\
\hline $\begin{array}{l}\text { Lemon tea } \\
\text { tree }\end{array}$ & $\begin{array}{l}\text { Leptospermum } \\
\text { petersonii F. M. Bailey }\end{array}$ & Myrtaceae & leaf & steam distilled & $\begin{array}{l}\text { neral, geranial, } \boldsymbol{\gamma} \text {-terpinene, geraniol, } \\
\text { geranyl acetate, } \alpha \text {-pinene, citronellal, } \\
\text { terpinolene }\end{array}$ & [67] & 1.4 \\
\hline Lime & Citrus $\times$ aurantifolia L. & Rutaceae & peel & $\begin{array}{l}\text { steam distilled, } \\
\text { pressed }\end{array}$ & $\begin{array}{l}\text { D-dihydrocarvone, } D \text {-limonene, } \\
\alpha \text {-terpineol }\end{array}$ & [68] & 2.1 \\
\hline Manuka & $\begin{array}{l}\text { Leptospermum } \\
\text { scoparium Forst. } \\
\text { \& Forst. }\end{array}$ & Myrtaceae & $\begin{array}{l}\text { leaf, } \\
\text { stem }\end{array}$ & steam distilled & $\begin{array}{l}\text { leptospermone, trans-calamenene, } \\
\text { flavesone, 1,8-cineole, } \boldsymbol{\alpha} \text {-pinene }\end{array}$ & {$[69,70]$} & 1.4 \\
\hline Marjoram & Origanum majorana L. & Lamiaceae & $\begin{array}{l}\text { leaf, } \\
\text { flower }\end{array}$ & steam distilled & $\begin{array}{l}\text { p-cymene, } \boldsymbol{\gamma} \text {-terpinene, terpinen-4-ol, } \\
\text { linalool, cis-sabinene hydrate }\end{array}$ & {$[71,72]$} & 2.1 \\
\hline $\begin{array}{l}\text { May chang/ } \\
\text { Litsea }\end{array}$ & $\begin{array}{l}\text { Litsea cubeba (Lour.) } \\
\text { Pers. }\end{array}$ & Lauraceae & fruit & steam distilled & neral, $\mathbf{R}-(+)$-limonene, geranial, citronellal & {$[46,73,74]$} & 4.9 \\
\hline $\begin{array}{l}\text { Melaleuca/ } \\
\text { Tea tree }\end{array}$ & $\begin{array}{l}\text { Melaleuca alternifolia } \\
\text { Cheel }\end{array}$ & Myrtaceae & leaf & steam distilled & $\begin{array}{l}\text { terpinen-4-ol, } \gamma \text {-terpinene, } \alpha \text {-terpinene, } \\
\text { 1,8-cineole }\end{array}$ & [75] & 9.7 \\
\hline $\begin{array}{l}\text { Mint, } \\
\text { mentha }\end{array}$ & Mentha L. spp. & Lamiaceae & $\begin{array}{l}\text { leaf, } \\
\text { flower }\end{array}$ & steam distilled & $\begin{array}{l}\text { menthone, menthol, 1,8-cineole, } \\
\text { 4-terpineol }\end{array}$ & [76] & 9.7 \\
\hline Orange & $\begin{array}{l}\text { Citrus } \times \text { sinensis (L.) } \\
\text { Osbeck }\end{array}$ & Rutaceae & peel & pressed & limonene, myrcene & [77] & 4.2 \\
\hline Palmarosa & $\begin{array}{l}\text { Cymbopogon martini } \\
\text { (Roxb.) Will.Watson }\end{array}$ & Poaceae & dry leaf & steam distilled & geraniol, geranyl acetate, geranial & [78] & 4.9 \\
\hline $\begin{array}{l}\text { Parsley } \\
\text { (Curl leaf) }\end{array}$ & $\begin{array}{l}\text { Petroselinum crispum } \\
\text { (Mill.) Fuss }\end{array}$ & Apiaceae & $\begin{array}{l}\text { leaf, stem, } \\
\text { seed }\end{array}$ & steam distilled & $\begin{array}{l}\beta \text {-phellandrene, myristicin, } \alpha \& \beta \text {-pinene, } \\
\text { myrcene }\end{array}$ & [79] & 1.4 \\
\hline Patchouli & $\begin{array}{l}\text { Pogostemon cablin } \\
\text { (Blanco) Benth. }\end{array}$ & Lamiaceae & $\begin{array}{l}\text { dry, } \\
\text { fermented } \\
\text { leaf }\end{array}$ & steam distilled & $\begin{array}{l}\text { (-)-patchoulol, } \alpha \text {-guaiene, seychellene, } \\
\beta \text {-caryophyllene, } \alpha \& \beta \text {-patchoulenes, selinene, } \\
\alpha \text {-bulnesene, norpatchoulenol, pogostol }\end{array}$ & [80] & 4.2 \\
\hline Pepper & Piper nigrum L. & Piperaceae & fruit & steam distilled & $E$ - $\beta$-caryophyllene, limonene, $\boldsymbol{\beta}$-pinene & {$[81,82]$} & 2.1 \\
\hline Peppermint & Mentha × piperita L. & Lamiaceae & $\begin{array}{l}\text { aerial } \\
\text { part }\end{array}$ & steam distilled & $\begin{array}{l}\text { isomenthol, } p \text {-menthone, isomenthyl \& } \\
\text { menthyl acetates }\end{array}$ & {$[83,84]$} & 16.7 \\
\hline Pine & Pinus sylvestris $\mathrm{L}$. & Pinaceae & $\begin{array}{l}\text { twig, } \\
\text { bud }\end{array}$ & steam distilled & $\begin{array}{l}\text { 3-carene, } \alpha \& \beta \text {-pinene, } \alpha \text {-cadinol, } \\
\text { camphene }\end{array}$ & {$[85,86]$} & 8.3 \\
\hline Rose & $\begin{array}{l}\text { Rosa } \times \text { damascena } \\
\text { Mill., } R . \times \text { centifolia L. }\end{array}$ & Rosaceae & petal & $\begin{array}{l}\text { steam distilled, } \\
\text { solvent extracted }\end{array}$ & $\begin{array}{l}\text { 2-phenethyl alcohol, citronellol, geraniol, } \\
\text { linalool, nonadecane }\end{array}$ & {$[30,87]$} & 6.3 \\
\hline
\end{tabular}


Table 1 Botanic information, extraction methods, major chemical components, literature sources and frequency (\%) of use of plant essential and glyceridic oils in patented mosquito repellent inventions, 1991 - May, 2010. (continued)

\begin{tabular}{|c|c|c|c|c|c|c|c|}
\hline Oil & Species & Family & Part & Method & Major components & Lit. & \% Patents \\
\hline \multicolumn{8}{|l|}{ Essential Oils } \\
\hline Rosemary & $\begin{array}{l}\text { Rosmarinus } \\
\text { officinalis L. }\end{array}$ & Lamiaceae & flower & steam distilled & $\begin{array}{l}\text { verbenone, camphor, borneol, bornyl } \\
\text { acetate, } \alpha \text {-terpineol, terpinen-4-ol }\end{array}$ & {$[41,88]$} & 9.0 \\
\hline Salvia (Sage) & Salvia L. spp. & Lamiaceae & $\begin{array}{l}\text { leaf, flower, } \\
\text { aerial part }\end{array}$ & steam distilled & $\begin{array}{l}\text { camphor, } 1,8 \text {-cineole, } \alpha \text {-pinene, camphene, } \\
\text { limonene, linalool, myrcene, } \beta \text {-caryophyllene, } \\
\text { caryophyllene oxide, spathulenol, viridiflorol, } \\
\text { 3-carene, } \alpha \text {-bisabolol, geraniol, linalyl } \\
\text { acetate, } \gamma \text {-muurolene, } \boldsymbol{\alpha} \text {-thujone, manool }\end{array}$ & [89-92] & 1.4 \\
\hline Sandalwood & Santalum L. spp. & Santalaceae & heartwood & steam distilled & $\begin{array}{l}\alpha, \beta \text { \& epi- } \beta \text {-santalenes; } \alpha, \beta \text { \& epi- } \beta \text {-santalals; } \\
\boldsymbol{\alpha} \text {-santalol; spiro, } \beta, E-\beta \text { \& epi- } \beta \text { santalols, } \\
\text { trans- } \alpha \text {-bergamotene, trans- } \alpha \text {-bergamotol }\end{array}$ & {$[80,93]$} & 3.5 \\
\hline $\begin{array}{l}\text { Sour (bitter) } \\
\text { orange }\end{array}$ & Citrus $\times$ aurantium L. & Rutaceae & peel & pressed & limonene & [94] & 3.5 \\
\hline Spearmint & Mentha spicata L. & Lamiaceae & flower & steam distilled & carvone, limonene & [95] & 2.8 \\
\hline Star anise & Illicium verum Hook. f. & Schisandraceae & seed & steam distilled & E-anethole, 4-allylanisole & {$[96,97]$} & see anise* \\
\hline Tagetes & Tagetes minuta $\mathrm{L}$. & Asteraceae & $\begin{array}{l}\text { leaf, } \\
\text { stalk, } \\
\text { flower }\end{array}$ & $\begin{array}{l}\text { steam distilled, } \\
\text { solvent } \\
\text { extracted }\end{array}$ & $\begin{array}{l}E \& Z \text { - } \beta \text {-ocimenes, limonene, } \boldsymbol{\alpha} \text {-terpineol, } \\
\text { dihydrotagetenone, Z-tagetone, } E \& \\
Z \text {-tagetenones }\end{array}$ & [98] & 2.1 \\
\hline Tarragon & Artemisia dracunculus $\mathrm{L}$. & Asteraceae & $\begin{array}{l}\text { leaf, } \\
\text { flower }\end{array}$ & steam distilled & sabinene, elemicine, methyl eugenol & [99] & 1.4 \\
\hline Thyme & Thymus vulgaris $\mathrm{L}$. & Lamiaceae & $\begin{array}{l}\text { flower, } \\
\text { leaf }\end{array}$ & steam distilled & $\begin{array}{l}\text { p-cymene, geraniol, cis-thujone, thymol, } \\
\text { carvacrol }\end{array}$ & [41] & 7.6 \\
\hline Turmeric & Curcuma longa L. & $\begin{array}{l}\text { Zingibera- } \\
\text { ceae }\end{array}$ & rhizome & $\begin{array}{l}\text { steam distilled, sol- } \\
\text { vent extracted }\end{array}$ & $\begin{array}{l}\alpha \text {-phellandrene, 1,8-cineole, terpinolene, } \\
\text { zingiberene, } \beta \text {-sesquiphellandrene, } \\
\alpha \& \beta \text {-turmerones }\end{array}$ & [41] & 2.8 \\
\hline Verbena & $\begin{array}{l}\text { Lippia triphylla } \\
\text { (L’Hér.) Kuntze }\end{array}$ & Verbenaceae & leaf & steam distilled & geranial, neral, limonene, geraniol & [100] & 1.4 \\
\hline Vetiver & $\begin{array}{l}\text { Vetiveria zizanioides (L.) } \\
\text { Nash }\end{array}$ & Poaceae & root & steam distilled & $\begin{array}{l}\text { khusimol, isonootkatool, } \beta \text {-vetivenene, } \\
\alpha \& \beta \text {-vetivones }\end{array}$ & [101] & 2.1 \\
\hline Violet & Viola odorata $\mathrm{L}$. & Violaceae & $\begin{array}{l}\text { leaf, } \\
\text { flower }\end{array}$ & solvent extracted & $\begin{array}{l}\text { nona-2,6-dienal, cis-hex-3-en-1-ol, hexadec- } \\
\text { 1-ene, pentadec-3-enal, octadec-1-ene, } \\
\text { hexadecanoic \& octadeca-9,12-dienoic acids }\end{array}$ & [102] & 1.4 \\
\hline Wintergreen & $\begin{array}{l}\text { Gaultheria } \\
\text { procumbens L. }\end{array}$ & Ericaceae & leaf & steam distilled & methyl salicylate & [103] & 6.3 \\
\hline Ylang-Ylang & $\begin{array}{l}\text { Cananga odorata (Lam.) } \\
\text { Hook. f. \& Thomson }\end{array}$ & Annonaceae & flower & steam distilled & $\begin{array}{l}\text { linalool, benzyl acetate, benzyl benzoate, } \\
\text { benzyl salicylate }\end{array}$ & [41] & 2.8 \\
\hline \multicolumn{8}{|c|}{ Glyceridic Oils } \\
\hline Castor & Ricinus communis L. & Euphorbiaceae & seed & pressed & ricinolic, linoleic, oleic acids & [104] & 4.9 \\
\hline $\begin{array}{l}\text { Evening } \\
\text { primrose }\end{array}$ & Oenothera biennis L. & Onagraceae & seed & pressed & $\begin{array}{l}\text { linalool; palmitic, stearic, oleic, linoleic \& } \\
y \text {-linolenic acids }\end{array}$ & $\begin{array}{l}{[105,} \\
106]\end{array}$ & 1.4 \\
\hline $\begin{array}{l}\text { Ligusticum/ } \\
\text { Chuanxiong }\end{array}$ & $\begin{array}{l}\text { Ligusticum chuanxiong } \\
\text { Hortorum ex Qiu, et al. } \\
\text { in Qiu }\end{array}$ & Apiaceae & root & $\mathrm{CO}_{2}$ extracted & $\begin{array}{l}\text { butylphthalide, 2-propenyl phenoxyacetate, } \\
\text { 3-isobutyliden phthalide, palmitic \& } \\
\text { octadecenoic acids }\end{array}$ & [107] & 1.4 \\
\hline Mustard & Brassica L. spp. & Brassicaceae & seed & Pressed & $\begin{array}{l}\text { erucic, oleic, linoleic, linolenic, palmitic \& } \\
\text { stearic acids }\end{array}$ & [108] & 2.1 \\
\hline Neem & $\begin{array}{l}\text { Azadirachta indica A. } \\
\text { Juss. }\end{array}$ & Meliaceae & seed & pressed & $\begin{array}{l}\text { salanin, nimbinin, nimbin, nimbidiol, } \\
\text { azadirachtin; palmitic, stearic, oleic, linoleic } \\
\text { acids }\end{array}$ & $\begin{array}{l}{[104,} \\
109]\end{array}$ & 8.3 \\
\hline Olive & Olea europaea L. & Oleaceae & fruit & pressed & oleic, palmitic, linoleic \& stearic acids & [110] & 2.1 \\
\hline Perilla & $\begin{array}{l}\text { Perilla frutescens (L.) } \\
\text { Britton }\end{array}$ & Lamiaceae & seed & pressed & $\begin{array}{l}\text { oleic, linoleic \& linolenic acids, S-limonene, } \\
\text { perillaldehyde, elsholzia- ketone, naginatake- } \\
\text { tone, perillaketone, myristicin, dillapiol, } \\
\text { elemicin, isoegomaketone, perillene, } \\
\text { egomaketone, shisofuran }\end{array}$ & {$[111-113]$} & 1.4 \\
\hline Sesame & Sesamum indicum $\mathrm{L}$. & Pedaliaceae & seed & pressed & linoleic, oleic, palmitic \& stearic acids & [114] & 3.5 \\
\hline Soybean & $\begin{array}{l}\text { Glycine max (L.) } \\
\text { Merr. }\end{array}$ & Fabaceae & seed & solvent extracted & $\begin{array}{l}\text { linoleic, oleic, palmitic, } \alpha \text {-linolenic \& stearic } \\
\text { acids }\end{array}$ & [115] & 4.2 \\
\hline
\end{tabular}

Note: chemical components in bold text have proven mosquito repellent and deterrent properties according to literature and patent sources which are summarized in $\bullet$ Table 4). Tropicos, botanical information system at the Missouri Botanical Garden [12] was used as a general reference on taxonomic information in this table

of potentially novel sources of mosquito repellent botanicals it is important to mention the following EOs: abies [Abies spectabilis (D. Don) Spach], almond [Prunus dulcis (Mill.) D. A.Webb], Austra- lian yuzu (Citrus junos Siebold ex Tanaka), black pine (Pinus nigra Arnold), Blumea lacera (Burm. f.) DC., calamus (Acorus calamus L.), Canada fleabane [Conyza canadensis (L.) Cronquist], carda- 
Table 2 Uses and applications, EOs and other components of patented mosquito repellent inventions which claimed synergist effects.

\begin{tabular}{|c|c|c|c|c|}
\hline Use or technology & Plant EO & Plant species & Non-EO component & Source \\
\hline Applied films & - & $\begin{array}{l}\text { Backhousia citriodora F. Muell. } \\
\text { Melaleuca ericifolia Sm. }\end{array}$ & - & [116] \\
\hline Coatings & $\begin{array}{l}\text { Wintergreen } \\
\text { Camphor }\end{array}$ & $\begin{array}{l}\text { Gaultheria procumbens } L \text {. } \\
\text { Cinnamomum camphora (L.) J. Presl }\end{array}$ & pyrethroids & [117] \\
\hline Floor wash & $\begin{array}{l}\text { Eucalyptus } \\
\text { Lemon eucalyptus } \\
\text { Citronella }\end{array}$ & $\begin{array}{l}\text { Eucalyptus L'Hér. spp. } \\
\text { Eucalyptus citriodora Hook. } \\
\text { Cymbopogon winterianus Jowitt ex Bor }\end{array}$ & - & [118] \\
\hline Incense & $\begin{array}{l}\text { Eucalyptus } \\
\text { Cassia }\end{array}$ & $\begin{array}{l}\text { Eucalyptus L’Hér. spp. } \\
\text { Cinnamomum cassia (L.) C. Presl }\end{array}$ & pyrethroids & [119] \\
\hline Microcapsules for textiles & Eucalyptus & Eucalyptus L'Hér. spp. & DEET, isobornyl derivatives & [120] \\
\hline Not specified & $\begin{array}{l}\text { Rose } \\
\text { Jasmine } \\
\text { Limonene }\end{array}$ & $\begin{array}{l}\text { Rosa L. sp. } \\
\text { Jasminum officinale L. } \\
\text { synergist natural product }\end{array}$ & natural pyrethrins & [121] \\
\hline Spray/Fumigation on grass, shrubs, trees & $\begin{array}{l}\text { Citronella } \\
\text { Neem } \\
\text { Eucalyptus }\end{array}$ & $\begin{array}{l}\text { Cymbopogon Spreng. sp. } \\
\text { Azadirachta indica A. Juss. } \\
\text { Eucalyptus L'Hér. spp. }\end{array}$ & dimethyl phthalate, allyl sulfate & [122] \\
\hline Vaporizer/Fumigant & $\begin{array}{l}\text { Lippia } \\
\text { Geranium } \\
\text { Lemon eucalyptus } \\
\text { Basil etc. }\end{array}$ & $\begin{array}{l}\text { Lippia L. sp.+: } \\
\text { Pelargonium graveolens L’Hér. } \\
\text { Eucalyptus citriodora Hook. } \\
\text { Ocimum basilicum L. }\end{array}$ & - & [123] \\
\hline
\end{tabular}

mom [Elettaria cardamomum (L.) Maton], cork tree (Phellodendron amurense Rupr.), Elsholtzia hunanensis Hand.-Mazz., flos lonicerae japonicae or jin yin hua (Lonicera japonica Thunb. ex Murray flower), fructus forsythiae [Forsythia suspensa (Thunb.) Vahl], galbanum (Ferula galbaniflua Boiss. \& Buhse), herba schizonepetae [Schizonepeta (Benth.) Briq. sp.], hibiscus (Hibiscus L. sp.), larch (Larix Mill. sp.), lemon balm (Melissa officinalis L.), lovage (Levisticum officinale W.D.J. Koch), lilac (Syringa vulgaris L.), Limnanthes alba Hartw. ex Benth. seed, linaloe wood (Bursera delpechiana Poiss. ex Engl.), Michelia $\times$ alba DC. leaf, myrtle (Myrtus communis L.), Ocimum canum Sims, onion (Allium cepa L.), oregano (Origanum vulgare L.), peach [Prunus persica (L.) Batsch], pennyroyal (Mentha pulegium L.), pepper (Capsicum annuum L. var. annuum), petitgrain (Citrus aurantium L. var. amara), pimento [Pimenta dioica (L.) Merr.], pine needle (Pinus L. sp.), Rhodomyrtus tomentosa (Aiton) Hassk., rue (Ruta graveolens L.), Stephania sinica Diels, tansy (Tanacetum L. sp.), Torreya grandis Fortune ex Lindl. and valerian (Valeriana L. sp.). Nevertheless, we will not systematically go into details of the composition and repellency of these EOs in this review.

Generally, patent literature on mosquito repellent inventions treats fragrant extracts as EOs whether these extracts are produced using an initial solvent extraction step (such as in the production of concretes), by steam distillation, hydrodistillation, direct distillation or pressing (resulting in proper EOs). Herein, the term EO refers broadly to fragrant extracts obtained using these different extraction techniques. Importantly, fragrant oils and partially volatile balsamic oils which have volatile and non-volatile (glyceridic) chemical components in their compositions ( Table 1) and mosquito repellent properties, such as evening primrose (Oenothera biennis L.), perilla [Perilla frutescens (L.) Britton], ligusticum (Ligusticum chuanxiong Hortorum ex Qiu, et al. in Qiu) and copaiba (Copaifera L. spp.) oils are used in mosquito repellent patented formulations together with plant EOs.

\section{Glyceridic Oils Used in Patented Mosquito Repellent Inventions $\nabla$}

Importantly, plant glyceridic oils, several of which are known to possess mosquito repellency, were used in patented formulations as carriers or active ingredients which were associated with prolonged repellent action. The most used glyceridic oils in patented EO-containing repellent inventions were neem/margarosa (Azadirachta indica A. Juss., 8.3\%), castor (Ricinus communis L., 4.9\%), soybean [Glycine $\max$ (L.) Merr., 4.2\%] and sesame (Sesamum indicum L., 3.5\%) oils (๑ Table 1).

\section{Synergist Effects Associated with EO-Containing Compositions \\ $\nabla$}

Synergist interactions were claimed to be operating in $8 \%$ of EOcontaining patents ( Table 2) [116-123]. For example, EO of a species of Lippia L. and any one of a number of EOs formulated into a slowly evaporating hydrocarbon soluble composition was said to modify neuronal activity in invertebrates such as adult mosquitoes and produce repellent activity comparable to commercial pyrethroids [123]. Another example of a synergist formulation involved almost equal amounts of eucalyptus (Eucalyptus spp.) and cassia [Cinnamomum cassia (L.) C. Presl] EOs together with an emulsifying agent and butyl acetate solvent which was meant to be used with pyrethroids in incense formulations [119]. Still another example of a synergist repellent meant for use with pyrethroids (allethrin, dimefluthrin) used EOs of wintergreen (Gaultheria procumbens L.) 30-50 (w/w) and camphor (Cinnamomum camphora (L.) J. Presl) 10-35 (w/w), emulsifier and solvent [117] ( Table 2 ). 
Scientific Basis for Mosquito Repellency of EOs in Patented Inventions

$\nabla$

The scientific literature on the mosquito repellence of EOs used in patents provides important insights ( Table 3 ) $[8,37,41,46,61$, $68,73,85,88,93,124-177]$. Firstly, citronella (Cymbopogon nardus, C. winterianus), eucalyptus (Eucalyptus spp.) and lemon eucalyptus (E. citriodora Hook.) EOs which were cited in many patented inventions have been the subject of a number of studies in which repellency against species of Culex, Anopheles and Aedes in some cases comparable to DEET have been reported for these oils alone or in formulations $[138,140,143,178]$. Furthermore, many EOs used in patented inventions have quite significant repellent properties according to published studies such as: bay laurel (Laurus nobilis L.) [137], camphor (Cinnamomum camphora) [132], cassia (Cinnamomum cassia) [132] EOs against Ae. aegypti; lemon (Citrus $\times$ limon) EO $[128,152]$ against An. stephensi Liston, catnip (Nepeta cataria L.) EO [128], lemongrass (Cymbopogon citratus) [128], may chong/litsea [Litsea cubeba (Lour.) Pers.] [128, 179], tagetes (Tagetes minuta L.) [128], violet (Viola odorata L.) EOs [128] against Ae. aegypti, An. stephensi and Cx. quinquefasciatus; peppermint (Mentha $\times$ piperita) EO on human skin against An. annularis van der Wulp, An. culicifacies Giles and $C x$. quinquefasciatus [160]; sandalwood (Santalum L. spp.) EO formulations against a Culex sp. [177]; geranium (Pelargonium graveolens) oil formulations [137, 144, 147, 148] against species of Culex, Anopheles and Aedes; thyme (Thymus vulgaris L.) EO against $C x$. quinquefasciatus $[128,137,162]$; marjoram (Origanum majorana L.) and juniper (Juniperus communis L.) EOs against $C x$. pipiens pallens Coquillet [151]; and wintergreen (Gaultheria procumbens) EO against species of Culex and Aedes [131].

A broad-scale screening of plant oils against Ae. aegypti, An. stephensi and $C x$. quinquefasciatus evaluated protection periods and percent of repellence on human skin as compared to $20 \%$ DEET [128]. In general, Ae. aegypti was the most difficult species to repel, followed by $A n$. stephensi and finally $C x$. quinquefasciatus for both oils and controls. The control (DEET) exhibited a protection period (PP) of $6 \mathrm{~h}$ and percent repellency (R\%) of $46 \%$ against $A$ e. aegypti, whereas against An. stephensi and Cx. quinquefasciatus protection was for $8 \mathrm{~h}$ at $100 \%$ repellency [128] (O Table 3). While the most active EOs against all three mosquito species were cited above, the following oils were active against An. stephensi and $C x$. quinquefasciatus, but not significantly active against Ae. aegypti: chamomile (Chamaemelum nobile), cinnamon (Cinnamomum verum), galbanum (Ferula galbaniflua), jasmine (Jasminum grandiflorum), lavender (Lavandula angustifolia), pepper (Piper nigrum), rosemary (Rosmarinus officinalis), sandalwood (Santalum album) and soybean (Glycine max) [128]. Another group of oils in this study actively repelled only $C x$. quinquefasciatus: cedar (Cedrus, Cupressus and Juniperus spp.), citronella (Cymbopogon nardus, C. winterianus), eucalyptus (Eucalyptus globulus), broad and narrow-leaved eucalyptus (E. dives and E. radiata, respectively), geranium (Pelargonium graveolens), juniper (Juniperus communis), lemon (Citrus $\times$ limon), lemon eucalyptus (Eucalyptus citriodora), myrtle (Myrtus communis), peppermint (Mentha $\times$ piperita), sage (Salvia sclarea), thyme (Thymus serpyllum) verbena (Lippia triphylla) and wild soybean (Glycine soja) [128]. Differences in the species specificity of the repellence profiles of these and other EOs may explain their use in repellent mosquito products. This may have to do with differences in the local and regional profiles of mosquito species populations and explain the use of mixtures of these EOs to generate broad spec- trum formulations for simultaneous repellency of multiple mosquito species.

While Ae. aegypti and other adults may in general be difficult to repel using plant-based products or synthetic repellents, a number of plant EOs have been identified which are effective against this species ( $\bigcirc$ Table 3 ). The following repellency effects of EOs against adult Ae. aegypti have been observed: hairy basil (Ocimum basilicum) in stable nanoemulsions with vetiver (Vetiveria zizanioides) and citronella (Cymbopogon nardus and C.winterianus) EOs are a good repellent [129], bay laurel (Laurus nobilis) EO is an acceptable smelling, good spatial repellent [130], camphor (Cinnamomum camphora) EO and cassia (C. cassia) bark extract on human skin are repellents comparable to DEET [137], catmint (Nepeta cataria) EO exhibited $8 \mathrm{~h}$ of protection on human skin, cinnamon (Cinnamomum zeylanicum, C. verum) EOs exhibit moderate to good repellency [128], citronella (C. winterianus) EO exhibits knockdown repellency at $1-2 \%$ [141] and $C$. winterianus EO + vanillin exhibits $8 \mathrm{~h}$ of repellency [138], fennel (Foeniculum vulgare) fruit extract/fractions offer complete repellency [145] and $\mathrm{EO}$ as an aerosol or cream has comparable repellency to other EO repellents [144], geranium (Pelargonium graveolens) + citronella EO in a cream product exhibited good repellency in the field [46], lemon eucalyptus (E. citriodora) has knockdown repellency/adulticide activity [46], may chang/litsea (Litsea cubeba) EO exhibits contact and noncontact repellency and is a good/excellent repellent in formulations on the human forearm providing protection over $8 \mathrm{~h}[73,128]$, turmeric (Curcuma longa) EO $+5 \%$ vanillin exhibits $8 \mathrm{~h}$ of repellency and in formulations with other EOs $+5 \%$ vanillin offers protection from DEET and IR3535resistant strains of Ae. aegypti over $4.5 \mathrm{~h}[138,156]$ and violet (Viola odorata) EO on human skin exhibited $8 \mathrm{~h}$ protection at a good level of repellency [128] ( $\odot$ Table 3).

Several EOs from Zanthoxylum L. spp. (Z. piperitum DC., Z. armatum DC., Z. bungei Planch. \& Linden ex Hance) were cited in patented mosquito repellent inventions. According to recent literature, Zanthoxylum L. spp. EOs have mosquito repellent activity $[159,180]$. Also, besides A. argyi H. Lév. \& Vaniot (artemisia) EO, which is known to repel mosquitoes [127], the EOs of several other Artemisia L. spp. were used in patented formulations such as A. annua L. (wormwood), A. vulgaris L. and A. apiacea Hance. This is interesting given that $A$. annua $\mathrm{EO}$ has proven insect repellent properties [165].

The Amazon region is a source of plant-derived mosquito repellent oils. For example, Carapa guianensis Aubl. (andiroba) pressed fruit oils or extracts are formulated preferentially into candles during manufacturing as fumigant mosquito repellents [124], burned in kerosene lamps or used in topical repellent formulations which are commercially available in Brazil. Copaifera L. spp. (copaiba) balsam oils or extracts are used in mosquito repellency in Brazil especially in the Amazon region (@ Table 3 ). Furthermore, a formulation of andiroba, copaiba and baby oils exhibited repellency to mosquitoes in an Amazon field study [125].

\section{Scientific Basis for Mosquito Repellency of Glyceridic Oils \\ $\nabla$}

Neem or margarosa oil is obtained by pressing the fruit of the neem tree (Azadirachta indica). Neem oil is burned in 1\% compositions in kerosene lamps as indoor mosquito emitters of chemical repellent-fumigant deterrents which have been evaluated and are considered to be safe $[173,174]$. Also, neem oil in mixtures 
Table 3 Scientific evidence for mosquito repellent and related properties of plant EOs and glyceridic oils used in patented repellent inventions.

\begin{tabular}{|c|c|c|c|}
\hline Plant oil & Plant species & Mosquito repellent properties & Source \\
\hline \multicolumn{4}{|l|}{ Essential oil } \\
\hline Andiroba & Carapa guianensis Aubl. & $\begin{array}{l}\text { patented candles commercialized in Brazil as mosquito fumigant-repellents; repellency in Amazon } \\
\text { field test of } 1: 1: 1 \text { andiroba, copaiba and baby oil mixture }\end{array}$ & {$[124,125]$} \\
\hline Anise & Pimpinella anisum L. & good repellent against $C x$. pipiens & [126] \\
\hline Artemisia & $\begin{array}{l}\text { Artemisia argyi H. Lév. } \\
\& \text { Vaniot }\end{array}$ & repels mosquitoes & [127] \\
\hline Basil & Ocimum basilicum L. & $\begin{array}{l}\text { Ae. aegypti (PP } 2 \mathrm{~h}, \mathrm{R} \% 81 \text { ), An. stephensi (PP } 3.5 \mathrm{~h}, \mathrm{R} \% 67), \text { Cx. quinquefasciatus (PP } 8 \mathrm{~h}, \mathrm{R} \% 100)^{*} \text {; } \\
5 \% \text { hairy basil }+5 \% \text { vetiver }+10 \% \text { citronella EOs in nanoemulsion repel Ae. aegypti } 4.7 \mathrm{~h} \text {; repels } \\
\text { Anopheles sp. in human bait test \& Cx. pipiens }\end{array}$ & {$[128,129]$} \\
\hline Bay laurel & Laurus nobilis L. & spatial repellence against $A e$. aegypti, acceptable smell, definite mosquito repellence & [130] \\
\hline Bergamot & Citrus $\times$ bergamia Risso & repellence against Culex \& Aedes spp. is comparable to citronella oil & [131] \\
\hline Camphor & $\begin{array}{l}\text { Cinnamomum } \\
\text { camphora (L.) J. Presl }\end{array}$ & $\begin{array}{l}\text { Ae. aegypti (PP } 2.5 \mathrm{~h}, \mathrm{R} \% 32) \text {, An. stephensi (PP } 8 \mathrm{~h}, \mathrm{R} \% 43) \text {, Cx. quinquefasciatus (PP } 8 \mathrm{~h}, \mathrm{R} \% 57)^{*} \text {; } \\
\text { EO (0.1 } \mathrm{mg} \cdot \mathrm{cm}^{-2} \text { on human skin): repellency and duration against Ae. aegypti comparable to DEET }\end{array}$ & {$[128,132]$} \\
\hline Cassia & $\begin{array}{l}\text { Cinnamomum cassia (L.) } \\
\text { C. Presl }\end{array}$ & $\begin{array}{l}\text { bark extract }\left(0.1 \mathrm{mg} \cdot \mathrm{cm}^{-2}\right) \text { : repels Ae. aegypti comparably to DEET (on human skin), } 5 \% \text { EO in cream } \\
\text { provided } 50 \mathrm{~min} \text { of protection to humans against female Ae. aegypti }\end{array}$ & [132] \\
\hline $\begin{array}{l}\text { Catnip, } \\
\text { catmint }\end{array}$ & Nepeta cataria L. & $\begin{array}{l}\text { Ae. aegypti (PP } 8 \mathrm{~h}, \mathrm{R} \% 84) \text {, An. stephensi (PP } 8 \mathrm{~h}, \mathrm{R} \% 100) \text {, Cx. quinquefasciatus (PP } 8 \mathrm{~h}, \mathrm{R} \% 100)^{*} \text {; } \\
\left.\text { 1-6 h protection against Ae. albopictus ( } 23 \& 468 \mathrm{\mu g} \cdot \mathrm{cm}^{-2}\right) \text {; safety pharmacology evaluation: } \\
\text { N. cataria oil is safe compared to DEET, } p \text {-menthane-3,8-diol, etc. May cause minor skin irritation }\end{array}$ & {$[128,133,134]$} \\
\hline Cedar & $\begin{array}{l}\text { Cedrus Trew (Cupressus } \\
\text { L., Juniperus L.) spp. }\end{array}$ & $\begin{array}{l}\text { Ae. aegypti (PP } 3 \text { h, R\% 38), An. stephensi (PP } 8 \text { h, R\% 38), Cx. quinquefasciatus (PP } 8 \text { h, R\% 100)*; } \\
\text { repels An. stephensi }\end{array}$ & {$[127,128,135]$} \\
\hline Chamomile & $\begin{array}{l}\text { Chamaemelum nobile } \\
\text { (L.) All. }\end{array}$ & Ae. aegypti (PP 4 h, R\% 65), An. stephensi (PP 8 h, R\% 76), Cx. quinquefasciatus (PP 8 h, R\% 100)* & [128] \\
\hline \multirow[t]{2}{*}{ Cinnamon } & $\begin{array}{l}\text { Cinnamomum } \\
\text { zeylanicum Blume }\end{array}$ & $\begin{array}{l}\text { high repellency }\left(\mathrm{RD}_{95} \mathrm{mg} \cdot \mathrm{mat}^{-1} \text { ) against An. stephensi (49.6), Ae. aegypti (53.9), }\right. \\
\text { Cx. quinquefasciatus (44.2) }\end{array}$ & [136] \\
\hline & C. verum J. Presl & Ae. aegypti (PP 5.5 h, R\% 70), An. stephensi (PP 8 h, R\% 100), Cx. quinquefasciatus (PP 8 h, R\% 100)* & [128] \\
\hline Citronella & $\begin{array}{l}\text { Cymbopogon nardus (L.) } \\
\text { Rendle, C. winterianus } \\
\text { Jowitt ex Bor }\end{array}$ & $\begin{array}{l}\text { repellency by } 1: 1 \text { citronella \& lavender EOs in } 2 \text { oz. castor oil; Ae. aegypti (PP } 2 \mathrm{~h}, \mathrm{R} \% 76 \text { ), An. stephensi } \\
\text { (PP } 8 \mathrm{~h}, \mathrm{R} \% 52 \text { ), CX. quinquefasciatus (PP } 8 \mathrm{~h}, \mathrm{R} \% 100)^{*} \text {; C. winterianus + vanillin repels Ae. aegypti, } \\
\text { An. dirus, CX. quinquefasciatus } 8 \mathrm{~h} \text {; + eucalyptus oil in floor cleaner, } 6 \mathrm{~h} \text { repellency; comparable to } \\
\text { DEET \& N,N-diethyl mandelic acid amide vs. Aedes spp.; } 5 \% \text { hairy basil + } 5 \% \text { vetiver }+10 \% \text { citronella EOs } \\
\text { in nanoemulsion with } 4.7 \mathrm{~h} \text { protection against Ae. aegypt; C. winterianus } \mathrm{LC} 50 \& \mathrm{LC}_{95}=0.5 \& 0.9 \% \text { for } \\
\text { CX. quinquefasciatus, } 1.0 \& 2.0 \% \text { for Ae. aegypti }\end{array}$ & $\begin{array}{l}{[37,128,129,} \\
137-141]\end{array}$ \\
\hline Clove & $\begin{array}{l}\text { Syzygium aromaticum (L.) } \\
\text { Merr. \& L. M. Perry }\end{array}$ & $\begin{array}{l}\text { Cx. pipiens pallens: isoeugenol \& eugenol (from clove oil) > repellency than citronella. Clove bud } \\
\text { oil + vanillin (long-term protection) > DEET; repels Ae. aegypti, An. dims, } C \text { x. quinquefasciatus for } \\
2-4 \mathrm{~h} \text {; knockdown } \mathrm{LC}_{50} \& \mathrm{LC}_{95}=0.5 \& 0.9 \% \text { for } C \text {. quinquefasciatus, } 1.0 \& 2.0 \% \text { for Ae. aegypti }\end{array}$ & {$[46,61,141]$} \\
\hline Copaiba & Copaifera L. spp. & $1: 1: 1$ andiroba, copaiba \& baby oils repels mosquitoes in Amazon field test & [125] \\
\hline Dill & Anethum graveolens L. & Ae. aegypti (PP 1.5 h, R\% 78), An. stephensi (PP 3.5 h, R\% 71), Cx. quinquefasciatus (PP 3 h, R\% 57)* & [128] \\
\hline \multirow[t]{3}{*}{ Eucalyptus } & Eucalyptus globulus Labill. & Ae. aegypti (PP 1 h, R\% 57), An. stephensi (PP 5.5 h, R\% 29), Cx. quinquefasciatus (PP 8 h, R\% 100)* & [128] \\
\hline & E. camaldulensis Dehnh. & EO repels $C$ x. pipiens adult females & [8] \\
\hline & Eucalyptus L’Hér. spp. & $\begin{array}{l}\text { + citronella EO in floor cleaning product, } 6 \mathrm{~h} \text { protection; } 15 \% \text { oil composition } \geq 3 \mathrm{~h} \text { protection \& } \\
\text { composition + vanillin } \geq 5 \mathrm{~h} \text { protection to humans; EO contg } 30 \% \text {-menthanediol repels An. darlingi ( } 97 \%)\end{array}$ & $\begin{array}{l}{[126,140,142,} \\
143]\end{array}$ \\
\hline $\begin{array}{l}\text { Eucalyptus, } \\
\text { broad-leaved }\end{array}$ & E. dives Schauer & Ae. aegypti (PP 3.5 h, R\% 19), An. stephensi (PP 8 h, R\% 38), Cx. quinquefasciatus (PP 8 h, R\% 100)* & [128] \\
\hline $\begin{array}{l}\text { Eucalyptus, } \\
\text { narrow-leaved }\end{array}$ & E. radiata Sieber ex DC. & Ae. aegypti (PP 2.5 h, R\% 65), An. stephensi (PP 8 h, R\% 43), Cx. quinquefasciatus (PP 8 h, R\% 100)* & [128] \\
\hline Fennel & Foeniculum vulgare Mill. & $\begin{array}{l}5 \% \text { in aerosol or } 8 \% \text { in cream repels Ae. aegypti comparably to citronella \& geranium EOs; cream \& EO } \\
\text { repel Culex, Anopheles \& Aedes spp. comparably to geranium \& citronella EOs in field; hexane fraction } \\
\left(0.1 \mathrm{mg} \cdot \mathrm{cm}^{-2} \text { repels Ae. aegypti } 99 \%\right) \text { of fruit methanol extract contains repellent (+)-fenchone \& } \\
\text { E-9-octadecenoic acid }\end{array}$ & {$[144,145]$} \\
\hline Galbanum & $\begin{array}{l}\text { Ferula galbaniflua } \\
\text { Boiss. \& Buhse }\end{array}$ & Ae. aegypti (PP 2.5 h, R\% 70), An. stephensi (PP 8 h, R\% 100), Cx. quinquefasciatus (PP 8 h, R\% 100)* & [128] \\
\hline Garlic & Allium sativum L. & EO and chemical components have strong repellent properties & [146] \\
\hline Geranium & $\begin{array}{l}\text { Pelargonium graveolens } \\
\text { L'Hér. }\end{array}$ & $\begin{array}{l}\text { Ae. aegypti (PP } 2.5 \mathrm{~h}, \mathrm{R} \% 78 \text { ), An. stephensi (PP } 8 \mathrm{~h}, \mathrm{R} \% 62) \text {, Cx. quinquefasciatus (PP } 8 \mathrm{~h}, \mathrm{R} \% 100)^{*} \text {; gera- } \\
\text { nium + lemongrass EOs repel Aedes spp.; geranium + sandalwood EOs + soybean oil in burned stick repel- } \\
\text { lents; geranium ( } 25 \% \text { geraniol) EO + lemongrass extract product protect against bites of Ae. atlanticus and } \\
\text { Ae. mitchellae for } 4 \mathrm{~h} \text {; geranium + sandalwood EOs + soybean oil product repel Culex sp. \& other } \\
\text { mosquitoes for } 3 \mathrm{~h} \text { in the field; geranium + citronella EOs }(1: 1) \text { in cream product repels Ae. aegypti } \\
\text { and Culex, Anopheles \& Aedes spp. in the field; in cold creams with repellency to } C x \text {. fatigans in lab \& } \\
\text { on humans; various forms of EO definite promise as repellents }\end{array}$ & $\begin{array}{l}{[46,128,137} \\
144,147,148]\end{array}$ \\
\hline Ginko & Ginkgo biloba L. & edulan (isolated from leaf extract) repels Ae. albopictus & [149] \\
\hline Hibawood & $\begin{array}{l}\text { Thujopsis dolabrata (Thunb. } \\
\text { ex L. f.) Siebold \& Zucc. }\end{array}$ & $\begin{array}{l}\text { hinokitiol isolated from EO, highly repellent hinokitiol-containing non-woven polyester fabric \& coated } \\
\text { foot band }\end{array}$ & [150] \\
\hline Jasmine & Jasminum grandiflorum L. & Ae. aegypti (PP 4.5 h, R\% 14), An. stephensi (PP 8 h, R\% 100), Cx. quinquefasciatus (PP 8 h, R\% 100)* & [128] \\
\hline Juniper & Juniperus communis $\mathrm{L}$. & $\begin{array}{l}\text { Ae. aegypti (PP } 3.5 \mathrm{~h}, \mathrm{R} \% 43 \text { ), An. stephensi (PP } 8 \mathrm{~h}, \mathrm{R} \% 76) \text {, Cx. quinquefasciatus (PP } 8 \mathrm{~h}, \mathrm{R} \% 100)^{*} \text {; } \\
\text { good repellency at } 5 \mathrm{\mu g} \cdot \mathrm{cm}^{-2} \text { against female } C x \text {. pipiens pallens }\end{array}$ & {$[128,151]$} \\
\hline
\end{tabular}


Table 3 Scientific evidence for mosquito repellent and related properties of plant EOs and glyceridic oils used in patented repellent inventions. (continued)

\begin{tabular}{|c|c|c|c|}
\hline Plant oil & Plant species & Mosquito repellent properties & Source \\
\hline \multicolumn{4}{|l|}{ Essential oil } \\
\hline Lavender & $\begin{array}{l}\text { Lavandula angustifolia } \\
\text { Mill. }\end{array}$ & $\begin{array}{l}\text { Ae. aegypti (PP } 3 \mathrm{~h}, \mathrm{R} \% 24) \text {, An. stephensi (PP } 8 \mathrm{~h}, \mathrm{R} \% 81 \text { ), Cx. quinquefasciatus (PP } 8 \mathrm{~h}, \mathrm{R} \% 86)^{*} \text {; mosquito } \\
\text { repellent: citronella 1: lavender } 1 \text { \& castor oil } 2 \mathrm{oz} \text {. }\end{array}$ & {$[127,128]$} \\
\hline Lemon & Citrus $\times$ limon (L.) Osbeck & $\begin{array}{l}\text { Ae. aegypti (PP 1.5 h, R\% 68), An. stephensi (PP } 7 \text { h, R\% 10), Cx. quinquefasciatus (PP } 8 \text { h, R\% 100)*; } \\
\text { repellency to An. stephensi DEET in animal \& human tests }\end{array}$ & {$[128,152]$} \\
\hline $\begin{array}{l}\text { Lemon } \\
\text { eucalyptus }\end{array}$ & $\begin{array}{l}\text { Eucalyptus citriodora } \\
\text { Hook. }\end{array}$ & $\begin{array}{l}\text { Ae. aegypti (PP } 2.5 \mathrm{~h}, \mathrm{R} \% 59 \text { ), An. stephensi (PP } 8 \mathrm{~h}, \mathrm{R} \% 52 \text { ), Cx. quinquefasciatus (PP } 8 \mathrm{~h}, \mathrm{R} \% 100)^{*} \text {; use } \\
\text { (p-menthane-3,8-diol, PMD, as active ingredient) recommended by CDC (Center for Disease Control and } \\
\text { Prevention, USA) against West Nile vector; adulticide activity against Cx. quinquefasciatus \& Ae. aegypti }\end{array}$ & {$[8,46,128]$} \\
\hline Lemongrass & $\begin{array}{l}\text { Cymbopogon citratus } \\
\text { (DC.) Stapf }\end{array}$ & $\begin{array}{l}\text { Ae. aegypti (PP } 3 \mathrm{~h}, \mathrm{R} \% \mathrm{70} \text { ), An. stephensi (PP } 8 \mathrm{~h}, \mathrm{R} \% 100) \text {, Cx. quinquefasciatus (PP } 8 \mathrm{~h}, \mathrm{R} \% 100 \text { ); field test } \\
\text { of } 25 \% \text { geraniol oil \& lemongrass ext. with } 4 \mathrm{~h} \text { repellency against Ae. atlanticus and Ae. mitchellae; mixture } \\
\text { containing lemongrass EO + p-menthanediol (PMD) repels An. darlingi \& other spp. } 95-98 \% \text { for } 5-6 \mathrm{~h} \text { in } \\
\text { field (repellency > } 15-20 \% \text { DEET) }\end{array}$ & {$[128,147,153]$} \\
\hline $\begin{array}{l}\text { Lemon } \\
\text { tea tree }\end{array}$ & $\begin{array}{l}\text { Leptospermum petersonii } \\
\text { F.M. Bailey }\end{array}$ & limited repellency (<DEET) of Ae. aegypti, Cx. quinquefasciatus, Cx. annulirostris & [154] \\
\hline $\begin{array}{l}\text { Lepto- } \\
\text { spermum }\end{array}$ & $\begin{array}{l}\text { L. liversidgei R.T. } \\
\text { Baker \& H. G. Sm. }\end{array}$ & repellent: blocks ability of mosquitoes to perceive $\mathrm{CO}_{2}$ emitted by humans & [155] \\
\hline Lime & Citrus $\times$ aurantifolia L. & + mustard oil carrier as effective mosquito repellent & [68] \\
\hline Marjoram & Origanum majorana & $5 \mu \mathrm{g} \cdot \mathrm{cm}^{-2}$ good repellent against female $C x$. pipiens pallens & [151] \\
\hline $\begin{array}{l}\text { May chang/ } \\
\text { Litsea }\end{array}$ & $\begin{array}{l}\text { Litsea cubeba (Lour.) } \\
\text { Pers. }\end{array}$ & $\begin{array}{l}\text { Ae. aegypti (PP } 8 \mathrm{~h}, \mathrm{R} \% 73 \text { ), An. stephensi (PP } 8 \mathrm{~h}, \mathrm{R} \% 100 \text { ), Cx. quinquefasciatus (PP } 8 \mathrm{~h}, \mathrm{R} \% 100 \text { )*; } \\
\text { high contact and noncontact repellency to female Ae. aegypti in vitro in cages; formulation to fix on } \\
\text { skin with high repellency in human volunteers for up to } 8 \mathrm{~h} \& 100 \% \text { repellency to An. stephensi, } \\
\text { Cx. quinquefasciatus, Ae. aegypti; greater repellence of night-biting mosquitoes An. dirus, } \\
\text { Cx. quinquefasciatus and Ae. albopictus than Ae. aegypti }\end{array}$ & $\begin{array}{l}{[73,128,132,} \\
156]\end{array}$ \\
\hline Melaleuca & Melaleuca alternifolia Cheel & limited repellence of Ae. aegypti, Cx. quinquefasciatus, Cx. annulirostris in lab & [75] \\
\hline Mint, mentha & Mentha haplocalyx Briq. & d-8-acetoxycarvotanacetone isolated mosquito repellent & [157] \\
\hline Myrtle & Myrtus communis L. & Ae. aegypti (PP $2.5 \mathrm{~h}, \mathrm{R} \% 57$ ), An. stephensi (PP $6.5 \mathrm{~h}, \mathrm{R} \% 43$ ), Cx. quinquefasciatus (PP $8 \mathrm{~h}, \mathrm{R} \% 86$ )* & [128] \\
\hline Palmarosa & $\begin{array}{l}\text { Cymbopogon martini } \\
\text { (Roxb.) Will.Watson }\end{array}$ & high geraniol content mosquito repellent & [158] \\
\hline Patchouli & $\begin{array}{l}\text { Pogostemon cablin } \\
\text { (Blanco) Benth. }\end{array}$ & partially repels Ae. aegypti, Cx. quinquefasciatus, An. dims & [159] \\
\hline Pepper, black & Piper nigrum L. & $\begin{array}{l}\text { Ae. aegypti (PP } 1.5 \text { h, R\% 65), An. stephensi (PP } 3 \text { h, R\% 62), Cx. quinquefasciatus (PP } 8 \text { h, R\% 100)*; } \\
\text { repels An. dirus, Cx. quinquefasciatus, Ae. albopictus ( } \geq 4.5 \text { h) }\end{array}$ & {$[128,156]$} \\
\hline Peppermint & Mentha $\times$ piperita L. & $\begin{array}{l}\text { Ae. aegypti (PP } 2 \text { h, R\% 59), An. stephensi (PP } 6.5 \mathrm{~h}, \mathrm{R} \% 57) \text {, Cx. quinquefasciatus (PP } 8 \mathrm{~h}, \mathrm{R} \% 100)^{*} \text {; } \\
\text { on human skin strongly repels An. annularis (100\%), An. culicifacies ( } 92 \% \text { ), Cx. quinquefasciatus ( } 85 \% \text { ); } \\
\text { comparable to mylol oil (di-butyl \& di-methyl phthalates); repels adult female Cx. pipiens }\end{array}$ & {$[126,128,160]$} \\
\hline Pine & Pinus sylvestris L. & good mosquito repellency & [85] \\
\hline Rose & Rosa L.sp. & moderate mosquito repellency & [127] \\
\hline Rosemary & Rosmarinus officinalis L. & $\begin{array}{l}\text { Ae. aegypti (PP } 5.5 \mathrm{~h}, \mathrm{R} \% 43 \text { ), An. stephensi (PP } 8 \mathrm{~h}, \mathrm{R} \% 100) \text {, Cx. quinquefasciatus (PP } 8 \mathrm{~h}, \mathrm{R} \% 100)^{*} \text {; } \\
\text { repels An. stephensi, Ae. aegypti \& Cx. quinquefasciatus; low repellency against Ae. aegypti in lab, } \\
\text { acceptable to humans as final fragrance in repellent formulation; repels Ae. aegypti (avg } 90 \mathrm{~min} \text { ) }\end{array}$ & $\begin{array}{l}{[88,128,130,} \\
136]\end{array}$ \\
\hline Sage & Salvia sclarea L. & Ae. aegypti (PP 2 h, R\% 46), An. stephensi (PP 5 h, R\% 19), Cx. quinquefasciatus (PP 8 h, R\% 100)* & [128] \\
\hline \multirow[t]{2}{*}{ Sandalwood } & Santalum album $\mathrm{L}$. & Ae. aegypti (PP 2.5 h, R\% 59), An. stephensi (PP 8 h, R\% 100), Cx. quinquefasciatus (PP 8 h, R\% 100)* & [128] \\
\hline & Santalum L. spp. & $\begin{array}{l}\text { repels } C x \text {. pipiens pallens; EO containing cold creams repel Cx. fatigans in the lab \& on human skin; } \\
\text { area repellency of Culex sp. by commercial sticks (contg } 0.5 \% \text { EO) ( } 3 \text { h protection); botanical repellent } \\
\text { (w/soybean and geranium oil) } 100 \% \text { effective in field ( } 3 \text {-h test period, comparable to DEET) }\end{array}$ & {$[93,148,151]$} \\
\hline $\begin{array}{l}\text { Sour (bitter) } \\
\text { orange }\end{array}$ & Citrus $\times$ aurantium L. & limited protection (repellency) against mosquitoes & [137] \\
\hline Spearmint & Mentha spicata L. & repellent; piperitone oxide from M. spicata (var. viridis) EO repels An. stephensi & [161] \\
\hline Tagetes & Tagetes minuta $\mathrm{L}$. & $\begin{array}{l}\text { Ae. aegypti (PP } 1 \text { h, R\% 84), An. stephensi (PP } 8 \text { h, R\% 100), CX. quinquefasciatus (PP } 8 \text { h, R\% 100)*; } \\
\text { repels Ae. aegypti (avg } 90 \text { min) }\end{array}$ & {$[88,128]$} \\
\hline \multirow[t]{2}{*}{ Thyme } & Thymus serpyllum L. & Ae. aegypti (PP 2.5 h, R\% 57), An. stephensi (PP 7.5 h, R\% 33), Cx. quinquefasciatus (PP 8 h, R\% 100)* & [128] \\
\hline & Thymus vulgaris $\mathrm{L}$. & repels lab-reared adult female Ae. albopictus for $2 \mathrm{~h} ; 0.01 \%$ totally repels $C x$. quinquefasciatus & {$[134,162]$} \\
\hline Turmeric & Curcuma longa L. & $\begin{array}{l}\text { + } 5 \% \text { vanillin repels Ae. aegypti, An. dirus and CX. quinquefasciatus in cage \& large room for } 8 \mathrm{~h} \text {; turmeric, } \\
\text { citronella \& hairy basil EOs + vanillin provide substitute for DEET; repels DEET \& IR3535-resistant } \\
\text { Ae. aegypti for } 4.5 \mathrm{~h}\end{array}$ & {$[138,156]$} \\
\hline Verbena & $\begin{array}{l}\text { Lippia triphylla (L’Hér.) } \\
\text { Kuntze }\end{array}$ & Ae. aegypti (PP 2.5 h, R\% 70), An. stephensi (PP 5.5 h, R\% 38), Cx. quinquefasciatus (PP 8 h, R\% 100)* & [128] \\
\hline Vetiver & $\begin{array}{l}\text { Vetiveria zizanioides (L.) } \\
\text { Nash }\end{array}$ & stable nanoemulsion of $5 \%$ hairy basil, $5 \%$ vetiver $\& 10 \%$ citronella EO: repels Ae. aegypti for $4.7 \mathrm{~h}$ & [41] \\
\hline Violet & Viola odorata L. & Ae. aegypti (PP 6 h, R\% 68), An. stephensi (PP 8 h, R\% 100), Cx. quinquefasciatus (PP 8 h, R\% 86)* & [128] \\
\hline $\begin{array}{l}\text { Wild verbena } \\
\text { (Lippie) }\end{array}$ & $\begin{array}{l}\text { Lippia sidoides, L. javanica, } \\
\text { Lippia spp. }\end{array}$ & sources of perillaldehyde (repels An. gambiae) \& perillic acid (repels An. arabiensis \& Ae. aegypti) & {$[163,164]$} \\
\hline Wintergreen & Gaultheria procumbens $\mathrm{L}$. & strongly repels Culex and Aedes spp. in different tests & [131] \\
\hline Wormwood & Artemisia annua L. & mosquito repellent properties & [165] \\
\hline
\end{tabular}


Table 3 Scientific evidence for mosquito repellent and related properties of plant EOs and glyceridic oils used in patented repellent inventions. (continued)

\begin{tabular}{|c|c|c|c|}
\hline Plant oil & Plant species & Mosquito repellent properties & Source \\
\hline \multicolumn{4}{|l|}{ Essential oil } \\
\hline Zanthoxylum & $\begin{array}{l}\text { Z. piperitum DC., } \\
\text { Z. armatum DC., } \\
\text { Z. bungei } \\
\text { Planch. \& Linden } \\
\text { ex Hance }\end{array}$ & repel mosquitoes & {$[159]$} \\
\hline \multicolumn{4}{|c|}{ Glyceridic oils } \\
\hline Castor & Ricinus communis L. & best carrier for pyrethrum extracts (long-lasting) & [137] \\
\hline Mustard & Brassica L. spp. & $\begin{array}{l}\text { longer protection (up to } 5 \mathrm{~h} \text { with Zanthoxylum limonella or lime oils) than coconut (Cocus nocifera) oil } \\
\text { against Ae. albopictus }\end{array}$ & {$[166]$} \\
\hline $\begin{array}{l}\text { Neem/ } \\
\text { Margosa }\end{array}$ & $\begin{array}{l}\text { Azadirachta indica A. } \\
\text { Juss. }\end{array}$ & $\begin{array}{l}\text { knockdown repellency against Ae. aegypti, Ae. albopictus, An. quadrimaculatus Say; repels female } \\
\text { An. stephensi (ED } 500.191-0.156 \mathrm{mg} \cdot \mathrm{cm}^{-2} \text { ) in lab; low repellency against Ae. albopictus \& Cx. nigripalpus; } \\
2 \% \text { in coconut (Cocus nocifera) oil on exposed body parts of human volunteers provided complete pro- } \\
\text { tection for } 12 \mathrm{~h} \text { from all Anopheles spp.; protection from Anopheles spp. ( } 96-100 \%) \text {, Aedes ( } 85 \%) \text {, Culex } \\
\text { sp. ( } 61-94 \%) \text {; significant protection by neem cream against adult Ae. aegypti; } 1 \% \text { in kerosene lamps in } \\
\text { preclinical \& clinical safety evaluation is safe to humans; } 1 \% \text { in kerosene burned in lamps effective in } 2 \\
\text { field tests. Repellence: Anopheles > Culex; } 1-4 \% \text { in coconut oil on exposed body parts of humans: } 81-91 \% \\
\text { protection for } 12 \mathrm{~h}\end{array}$ & {$[167-175]$} \\
\hline Olive & Olea europaea L. & $\begin{array}{l}\text { Ae. aegypti (PP } 3.5 \text { h, R\% 68), An. stephensi (PP } 8 \text { h, R\% 71), Cx. quinquefasciatus (PP } 8 \text { h, R\% 71)*; } \\
1: 1 \text { w/pyrethrum repels mosquitoes for } 4 \mathrm{~h}\end{array}$ & {$[128,137]$} \\
\hline Soybean & Glycine max (L.) Merr. & $\begin{array}{l}\text { Ae. aegypti (PP } 3 \mathrm{~h}, \mathrm{R} \% 54) \text {, An. stephensi (PP } 8 \mathrm{~h}, \mathrm{R} \% 76 \text { ), Cx. quinquefasciatus (PP } 8 \mathrm{~h}, \mathrm{R} \% 100)^{*} \text {; } \\
\text { oil-based product provided } 1.5 \mathrm{~h} \text { (low) repellency, } 24 \% \mathrm{DEET} \text { provided } 5 \text { h protection; good repellency } \\
\text { in product w/sandalwood + geranium in burned sticks vs. DEET; commercial product containing } 2 \% \\
\text { oil repels Ae. albopictus, Cx. nigripalpus, Ae. triseriatus for } 5,8.5 \& \geq 7.3 \mathrm{~h} \text {, respectively }\end{array}$ & $\begin{array}{l}{[128,169,176,} \\
177]\end{array}$ \\
\hline $\begin{array}{l}\text { Soybean, } \\
\text { wild (carotin) }\end{array}$ & $\begin{array}{l}\text { Glycine soja } \\
\text { Siebold \& Zucc. }\end{array}$ & Ae. aegypti (PP 3 h, R\% 16), An. stephensi (PP 8 h, R\% 10), Cx. quinquefasciatus (PP 8 h, R\% 100)* & {$[128]$} \\
\hline
\end{tabular}

* PP = protection period (h), $\mathrm{R} \%=$ percent repellency; $0.1 \mathrm{~mL}$ of a $20 \%$ EO solution (in $20 \%$ Genapol, $10 \% \mathrm{PEG}, 20 \%$ ethanol, $50 \%$ water) applied to $30 \mathrm{~cm}{ }^{2}$ of human forearm; for $20 \%$ DEET solution (in same as above) these values were: Ae. aegypti (PP 6 h, R\% 46), An. stephensi (PP 8 h, R\% 100), Cx. quinquefasciatus (PP 8 h, R\% 100) [24]

with coconut (Cocos nucifera L.) oil provides good protection for very long periods against Anopheles and Aedes spp. [170,171, 175]. Castor (Ricinus communis L.), mustard (Brassica spp.), olive (Olea europaea) and other glyceridic oils have important roles in several patented repellent compositions containing pyrethrum extracts and EOs where they act as carriers and can extend the duration of repellent effects for several hours perhaps by slowing the release or evaporation of EOs from surfaces.

There are mixed scientific reports on the effective mosquito repellency of several glyceridic oils. Thus, for soybean (Glycine max) oil low repellency was observed as compared to $24 \%$ DEET formulations [176] and good repellency was observed for the smoke generated from burned sticks which contained soybean oil. Especially interesting is a report from a United States Department of Agriculture laboratory where 4 well-known synthetic mosquito repellents based on 10\% KBR3023 [1-piperidinecarboxylic acid 2-(2-hydroxyethyl)-1-methylpropyl ester], 7.5\% IR3535 [3-( $N$-butyl- $N$-acetyl)-aminopropionic acid ethyl ester], $15 \%$ and $7 \%$ DEET and 8 natural product-based repellents based on $2 \%$ soybean oil, 10\% citronella (Cymbopogon spp.) EO, neem oil (Azadirachta indica) and others were tested in the lab against Ae. albopictus Skuse, Cx. nigripalpus Theobald and Ae. triseriatus Say [169]. The $2 \%$ soybean oil formulation exhibited mosquito repellency comparable to both 10\% KBR3023 and 15\% DEET based products each of which provided estimated mean protection time (eMPT) responses averaged over all three mosquito species of $\geq 7.2 \mathrm{~h}$ [169]. This study is evidence for the potential of soybean oil as a stand-alone repellent and as a component oil of repellent formulations.

\section{Mosquito Repellent Chemical Components of EOs and Added Isolated Compounds $\nabla$}

Approximately $20 \%$ of all EO-containing patents mentioned a non-EO plant derivative and $40 \%$ mentioned a specific EO repellent component or added isolated natural chemical ingredient. Chrysanthamic acid and its derivatives which are components of pyrethrum (Chrysanthemum L. spp. flower extracts) were cited in $12 \%$ of all patented formulations involving EOs. Also, patents cited many "natural" chemical constituents which were either added to formulations or were important chemical components of EOs comprising the formulations. The most widely cited chemicals of plant origin were (\% of patents): camphor (8.3), geraniol (7.6), linalool (7.6), menthol (7.6), geranial (7.0), citronellal (6.9), limonene (4.9), citronellol (4.9), borneol (4.2), 1,8-cineole (4.2), p-menthane-3,8-diol (4.2), camphene (3.5) and nepetalactone and derivatives (3.5). Many of these and other chemical components of EOs are potent mosquito repellents ( Table 4) [131, $137,143,145,151,163,169,181-193]$ and are discussed below.

\section{Vanillin in EO containing mosquito repellent inventions}

Vanillin was cited as an additive in $4 \%$ of EO-containing patents. According to several scientific publications, it increases the duration and magnitude of the repellent effect of synthetic repellents such as DEET as well as plant EOs. For example, $5 \%$ vanillin in formulations of EOs of turmeric (Curcuma longa L.), citronella (C. winterianus) or hairy basil (Ocimum americanum L.) provided up to $8 \mathrm{~h}$ of protection against Ae. aegypti, An. dirus and Cx. quinquefasciatus under cage conditions. Interestingly, $5 \%$ vanillin in formulations with DEET increased the protection time as compared to DEET alone against these three mosquito species ( $\geq 8 \mathrm{~h}$ protec- 
Table 4 Mosquito repellency or deterrency effects of individual major chemical components of EOs used in patented inventions.

\begin{tabular}{|c|c|c|c|c|}
\hline EO component & No. EOs ${ }^{\dagger}$ & Repellency & Mosquito & Source \\
\hline$\alpha$-Bisabolol & 2 & d84\% spatial repellency for $180 \mathrm{~min}$, avoidance freq. (contact repellency) = DEET & female Ae. aegypti & [181] \\
\hline \multirow[t]{2}{*}{ Borneol } & 3 & b1.4 $\mathrm{mg}(-)$-borneol $\cdot \mathrm{cm}^{-2}=70 \%$ repellency & female Ae. aegypti & [182] \\
\hline & & $\mathrm{b}, \mathrm{C} \mathrm{RD}_{50}=1.7 \times 10^{-3} \mathrm{mg} \cdot \mathrm{cm}^{-2}$ & female An. gambiae & [163] \\
\hline Bornyl acetate & 2 & ${ }^{b} 1.4 \mathrm{mg} \cdot \mathrm{cm}^{-2}=15 \%$ repellency & female Ae. aegypti & [182] \\
\hline Camphene & 2 & $\mathrm{~b}, \mathrm{CRD}_{50}=2.2 \times 10^{-3} \mathrm{mg} \cdot \mathrm{cm}^{-2}$ & female An. gambiae & [163] \\
\hline \multirow[t]{2}{*}{ Camphor } & 6 & $\mathrm{~b}, \mathrm{CRD}_{50}=1.4 \times 10^{-3} \mathrm{mg} \cdot \mathrm{cm}^{-2}$ & female An. gambiae & [163] \\
\hline & & $\begin{array}{l}\text { b1.4 } \mathrm{mg} \cdot \mathrm{cm}^{-2}( \pm) \text {-camphor, }(+) \text {-camphor, }(-) \text {-camphor }=36,35 \& 47 \% \\
\text { repellencies, resp. }\end{array}$ & female Ae. aegypti & [182] \\
\hline \multirow[t]{2}{*}{ 3-Carene } & 4 & $\mathrm{~b}, \mathrm{CRC}_{50}=8.6 \times 10^{-4} \mathrm{mg} \cdot \mathrm{cm}^{-2}$ & female An. gambiae & [183] \\
\hline & & $1 \mathrm{~h}, 1.92 \mu \mathrm{g} \cdot \mathrm{cm}^{-2}=68^{\dagger}, 65 \div \%$ repellency & Ae. aegypti, Ae. albopictus & [163] \\
\hline Carvacrol & 4 & $\mathrm{~b}, \mathrm{CRC}_{50}=2.4 \times 10^{-4} \mathrm{mg} \cdot \mathrm{cm}^{-2}$ & female An. gambiae & [183] \\
\hline \multirow[t]{2}{*}{ Carvone } & 2 & $\mathrm{~b}, \mathrm{CRD}_{50}=1.3 \times 10^{-3} \mathrm{mg} \cdot \mathrm{cm}^{-2}$ & female An. gambiae & [163] \\
\hline & & $\begin{array}{l}\text { d-carvone \& /-carvone: feeding deterrents/repellents, good spatial repellents/ } \\
\text { inhibitors, contact repellents/deterrents }\end{array}$ & - & [184] \\
\hline \multirow[t]{2}{*}{ Cinnamaldehyde } & 2 & definite mosquito repellent potential & - & [137] \\
\hline & & $\begin{array}{l}\text { E-cinnamaldehyde }\left(0.051 \mathrm{mg} \cdot \mathrm{cm}^{-2}\right) \& D E E T\left(0.025 \mathrm{mg} \cdot \mathrm{cm}^{-2}\right) \text { provided } \\
87 \& 95 \% \text { protection, resp., after } 30 \mathrm{~min}\end{array}$ & female Aedes aegypti & [184] \\
\hline \multirow[t]{3}{*}{ 1,8-Cineole } & 15 & ${ }^{b}$ cineole $1.4 \mathrm{mg} \cdot \mathrm{cm}^{-2}=21 \%$ repellency & female Ae. aegypti & [182] \\
\hline & & $\mathrm{b} 3 \%$ in vaseline or olive oil $=73$ or 120 min protection & $1: 1$ male: female $C x$. pipiens molestus & {$[185]$} \\
\hline & & $\mathrm{b}, \mathrm{CRD} \mathrm{D}_{50}=1.2 \times 10^{-3} \mathrm{mg} \cdot \mathrm{cm}^{-2}$ & female An. gambiae & [163] \\
\hline \multirow[t]{2}{*}{ Citronellal } & 4 & $\mathrm{~b}, \mathrm{CRD}_{50}=2.2 \times 10^{-4} \mathrm{mg} \cdot \mathrm{cm}^{-2}$ & female An. gambiae & [163] \\
\hline & & feeding deterrent/repellent, spatial repellent/inhibitor, contact repellent/deterrent & - & [186] \\
\hline \multirow[t]{2}{*}{ Citronellol } & 6 & repellent component & - & [145] \\
\hline & & feeding deterrent/repellent, spatial repellent/inhibitor & - & [186] \\
\hline p-Cymene & 3 & $\mathrm{~b}, \mathrm{C} \mathrm{RD}_{50}=1.0 \times 10^{-5} \mathrm{mg} \cdot \mathrm{cm}^{-2}$ & female An. gambiae & [163] \\
\hline \multirow[t]{2}{*}{ Eugenol } & 5 & high repellency & female $C$ x. pipiens pallens & [151] \\
\hline & & $\mathrm{b}, \mathrm{CRD}_{50}=1.3 \times 10^{-3} \mathrm{mg} \cdot \mathrm{cm}^{-2}$ & female An. gambiae & [163] \\
\hline \multirow[t]{2}{*}{ Fenchone } & 2 & $\mathrm{~b}, \mathrm{c} \mathrm{RD}_{50}=1.9 \times 10^{-3} \mathrm{mg} \cdot \mathrm{cm}^{-2}$ & female An. gambiae & [163] \\
\hline & & $0.4 \mathrm{mg}(+)$-fenchone $\cdot \mathrm{cm}^{-2}=51 \%$ repellency after $1 \mathrm{~h}^{\mathrm{b}, \mathrm{f}}$ & female Ae. aegypti & [145] \\
\hline Geranial & 7 & $\begin{array}{l}\text { at } 0.2 \mathrm{mg} \cdot \mathrm{cm}^{-2} \text {, blood-sucking by mosquitoes reduced by } 10,15 \text {, and } 18 \% \text { after } \\
1,2 \text { and } 3 \mathrm{~h} \text {, respectively }\end{array}$ & $\begin{array}{l}\text { Cx. pipiens pallens, } C x \text {. pipiens } \\
\text { quinquefasciatus }\end{array}$ & [187] \\
\hline \multirow[t]{2}{*}{ Geraniol } & 11 & $\mathrm{~b}, \mathrm{CRD}_{50}=1.1 \times 10^{-4} \mathrm{mg} \cdot \mathrm{cm}^{-2}$ & female An. gambiae & [163] \\
\hline & & $\begin{array}{l}\text { spatial repellent: } 0.25 \mu \mathrm{g} \cdot \mathrm{cm}^{-2} \mathrm{ca} .100 \% \text { (reversible) inhibition of host-seeking } \\
\text { after } 48 \text { h exposure }\end{array}$ & female Ae. albopictus & {$[188]$} \\
\hline Geranyl acetate & 6 & $\begin{array}{l}\text { effective feeding deterrent/repellent, effective spatial repellent/inhibitor, } \\
\text { contact repellent/deterrent }\end{array}$ & Mosquitoes & [186] \\
\hline \multirow[t]{3}{*}{ Limonene } & 19 & b3 $\%$ in vaseline/olive oil $=61 / 78$ min protection & $1: 1$ male: female $C x$. pipiens molestus & [185] \\
\hline & & $1 \mathrm{~h}, 1.92 \mu \mathrm{g} \cdot \mathrm{cm}^{-2}=70^{\dagger}, 70^{\ddagger} \%$ repellency & Ae. aegypti, Ae. albopictus & [189] \\
\hline & & $\mathrm{b}, \mathrm{CRD}_{50}=1.8 \times 10^{-3} \mathrm{mg} \cdot \mathrm{cm}^{-2}$ & female An. gambiae & [163] \\
\hline \multirow[t]{3}{*}{ Linalool } & $14^{*}$ & ${ }^{\mathrm{b}} 1.4 \mathrm{mg}( \pm)$-linalool $\cdot \mathrm{cm}^{-2}=67 \%$ repellency & female Ae. aegypti & [182] \\
\hline & & $\mathrm{b} 3 \%$ in vaseline $/$ olive oil $=52 / 65$ min protection & $1: 1$ male: female $C x$. pipiens molestus & {$[185]$} \\
\hline & & $\mathrm{b}, \mathrm{C} \mathrm{RD}_{50}=1.5 \times 10^{-3} \mathrm{mg} \cdot \mathrm{cm}^{-2}$ & female An. gambiae & [163] \\
\hline \multirow[t]{2}{*}{ p-Menthane-3,8-diol } & 1 & $26 \%$ formula more repellent than 4 synthetic $\& 7$ natural product repellents & $\begin{array}{l}\text { Ae. albopictus, Cx. nigripalpus, } \\
\text { Ochlerotatus triseriatus }\end{array}$ & [169] \\
\hline & & $\begin{array}{l}15 \% \text { formula with lemongrass EO (Cymbopogon citratus) }=99 \% \text { protection } \\
\text { for } 5 \mathrm{~h} \text { in the field; }{ }^{\mathrm{h}} 16 \% \text { formula with lemongrass } E O=95 \% \text { protection for } 6 \mathrm{~h} \\
\text { in the field }\end{array}$ & $\begin{array}{l}\text { An. darling, Ae. ochlerotatus } \\
\text { taeniorhynchus }\end{array}$ & [143] \\
\hline Menthone & 2 & b3\% in olive oil = 35 min protection & $1: 1$ male : female $C x$. pipiens molestus & [185] \\
\hline Methyl salicylate & 2 & most repellent (screening) & - & [131] \\
\hline \multirow[t]{2}{*}{ Myrcene } & 6 & $\mathrm{~b}, \mathrm{CRC}_{50}=8.4 \times 10^{-4} \mathrm{mg} \cdot \mathrm{cm}^{-2}$ & female An. gambiae & [183] \\
\hline & & ${ }^{b} 1.4 \mathrm{mg} \cdot \mathrm{cm}^{-2}=20 \%$ repellency & Ae. aegypti & [182] \\
\hline Nepetalactone & 1 & mosquito repellent ingredient in formulations & - & [190] \\
\hline E-Nerolidol & 1 & d67\% spatial repellency for $180 \mathrm{~min}$, avoidance freq. (contact repellency) < DEET & female Ae. aegypti & [181] \\
\hline Oleic acid & $8^{* *}$ & $0.4 \mathrm{mg} \cdot \mathrm{cm}^{-2}=52 \%$ repellency after $1 \mathrm{~h}^{\mathrm{b}, \mathrm{f}}$ & female Ae. aegypti & [145] \\
\hline Perillaldehyde & 1 & $\mathrm{~b}, \mathrm{CRD}_{50}=3.2 \times 10^{-4} \mathrm{mg} \cdot \mathrm{cm}^{-2}$ & female An. gambiae & [163] \\
\hline \multirow[t]{2}{*}{$\alpha$-Pinene } & 15 & $d$ - $\alpha$-pinene, 2 h protection & Mosquito & $\begin{array}{l}{[191,} \\
192]\end{array}$ \\
\hline & & $b_{3} \%$ in vaseline $/$ olive oil $=27 / 56$ min protection & 1:1 male:female $C x$. pipiens molestus & {$[185]$} \\
\hline \multirow[t]{2}{*}{$\beta$-Pinene } & 8 & $b_{3} \%$ in vaseline $/$ olive oil $=22 / 39$ min protection & $1: 1$ male:female $C x$. pipiens molestus & {$[185]$} \\
\hline & & $\mathrm{b}, \mathrm{CRD} \mathrm{D}_{50}=1.6 \times 10^{-3} \mathrm{mg} \cdot \mathrm{cm}^{-2}$ & female An. gambiae & [163] \\
\hline$\alpha$-Santalol & 1 & d87\% spatial repellency for $180 \mathrm{~min}$, avoidance freq. (contact repellency) = DEET & female Ae. aegypti & [181] \\
\hline Spathulenol & 2 & eproportion not biting $=0.73,0.75$, respectively & Ae. aegypti, An. stephensi & [193] \\
\hline
\end{tabular}


Table 4 Mosquito repellency or deterrency effects of individual major chemical components of EOs used in patented inventions. (continued)

\begin{tabular}{|c|c|c|c|c|}
\hline EO component & No. EOs ${ }^{\dagger}$ & Repellency & Mosquito & Source \\
\hline \multirow[t]{3}{*}{$\alpha$-Terpinene } & 1 & $1 \mathrm{~h}, 1.92 \mu \mathrm{g} \mathrm{cm}^{2}=688^{\dagger}, 55 \div \%$ repellency & Ae. aegypti, Ae. albopictus & [189] \\
\hline & & ${ }^{\mathrm{b}} 1.4 \mathrm{mg} \cdot \mathrm{cm}^{-2}=15 \%$ repellency & female Ae. aegypti & [182] \\
\hline & & $\mathrm{b}, \mathrm{CRD}_{50}=2.4 \times 10^{-3} \mathrm{mg} \cdot \mathrm{cm}^{-2}$ & female An. gambiae & [163] \\
\hline \multirow[t]{3}{*}{ y-Terpinene } & 6 & $1 \mathrm{~h}, 1.92 \mu \mathrm{g} \cdot \mathrm{cm}^{-2}=60^{\dagger}, 72^{\ddagger} \%$ repellency & Ae. aegypti, Ae. albopictus & [189] \\
\hline & & $\mathrm{b}_{3} \%$ in vaseline/olive oil $=35 / 48 \mathrm{~min}$ protection & $1: 1$ male: female $C x$. pipiens molestus & {$[185]$} \\
\hline & & $\mathrm{b}, \mathrm{CRD}_{50}=2.7 \times 10^{-3} \mathrm{mg} \cdot \mathrm{cm}^{-2}$ & female An. gambiae & {$[163]$} \\
\hline \multirow[t]{4}{*}{ Terpinen-4-ol } & 5 & $1 \mathrm{~h}, 1.92 \mu \mathrm{g} \cdot \mathrm{cm}^{-2}=92^{\dagger}, 85^{\ddagger} \%$ repellency & Ae. aegypti, Ae. albopictus & {$[189]$} \\
\hline & & b1 $1.4 \mathrm{mg} \cdot \mathrm{cm}^{-2}=83 \%$ repellency & Ae. aegypti & [182] \\
\hline & & $\mathrm{b}, \mathrm{CRD}_{50}=1.5 \times 10^{-3} \mathrm{mg} \cdot \mathrm{cm}^{-2}$ & female An. gambiae & {$[163]$} \\
\hline & & spatial repellent/inhibitor & - & [186] \\
\hline \multirow[t]{3}{*}{$\alpha$-Terpineol } & 7 & $b_{3} \%$ in vaseline/olive oil = 78/99 min protection & $1: 1$ male: female $C x$. pipiens molestus & {$[185]$} \\
\hline & & feeding deterrent/repellent, spatial repellents/inhibitor, contact repellent/deterrent & & [186] \\
\hline & & $\mathrm{b}, \mathrm{CRD}_{50}=1.3 \times 10^{-3} \mathrm{mg} \cdot \mathrm{cm}^{-2}$ & female An. gambiae & [163] \\
\hline \multirow[t]{2}{*}{ Terpinolene } & 2 & $1 \mathrm{~h}, 1.92 \mu \mathrm{g} \cdot \mathrm{cm}^{-2}=55^{\dagger}, 70^{\ddagger} \%$ repellency & Ae. aegypti, Ae. albopictus & [189] \\
\hline & & $\mathrm{b}, \mathrm{CRD}_{50}=2.6 \times 10^{-3} \mathrm{mg} \cdot \mathrm{cm}^{-2}$ & female An. gambiae & [163] \\
\hline \multirow[t]{2}{*}{$(\alpha+\beta)$-Thujone } & 2 & $\mathrm{~b} 1.4 \mathrm{mg} \cdot \mathrm{cm}^{-2}=20 \%$ repellency & Ae. aegypti & {$[182]$} \\
\hline & & $\mathrm{b}, \mathrm{c} R D_{50}=1.5 \times 10^{-3} \mathrm{mg} \cdot \mathrm{cm}^{-2}$ & female An. gambiae & [163] \\
\hline \multirow[t]{2}{*}{ Thymol } & 1 & $\mathrm{~b}, \mathrm{CRC}_{50}=1.9 \times 10^{-3} \mathrm{mg} \cdot \mathrm{cm}^{-2}$ & female An. gambiae & [183] \\
\hline & & $b_{3} \%$ in vaseline/olive oil $=52 / 65$ min protection & $1: 1$ male: female $C x$. pipiens molestus & {$[186]$} \\
\hline cis-Verbenol & 1 & $\mathrm{~b}, \mathrm{CRD}_{50}=7.5 \times 10^{-5} \mathrm{mg} \cdot \mathrm{cm}^{-2}$ & female An. gambiae & [163] \\
\hline Verbenone & 1 & $\mathrm{~b}^{\mathrm{b}} \mathrm{CRD}_{50}=1.6 \times 10^{-3} \mathrm{mg} \cdot \mathrm{cm}^{-2}$ & female An. gambiae & [163] \\
\hline
\end{tabular}

- = Information not found. ${ }^{\dagger}$ Number of oils in $\bigcirc$ Table 1 which contain this as their major component. *In evening primrose (Oenothera biennia) glyceridic oil. ${ }^{* *}$ Mosquito repellent component of glyceridic oils. ${ }^{\dagger}$ DEET $=50 \%$ repellency. ${ }^{\ddagger}$ DEET $=60 \%$ repellency. ${ }^{\text {a }}$ Used as additive in one patent. ${ }^{b}$ Human-bait assay. ${ }^{c}$ Positive control DEET exhibited $R C_{50}=3.3 \times$ $10^{-4} \mathrm{mg} \cdot \mathrm{cm}^{-2}$. ${ }^{\mathrm{d}}$ Applied concentration $78.6 \mu \mathrm{g} \cdot \mathrm{cm}^{-2}$. Repellency is statistically different from negative control. DEET and turmerone had 83 and $89 \%$ repellencies, respectively.

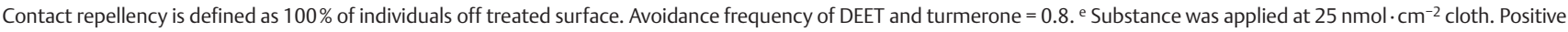
control was (1S,2'S)-2-methylpiperidinyl-3-cyclohexen-1-carboxamide (SS-220) at $25 \mathrm{nmol} \cdot \mathrm{cm}^{-2}$ cloth (provided 0.80 and 0.78 non-biting mosquitoes, respectively, for Ae. aegypti and An. stephensi). ${ }^{f} 0.2 \mathrm{mg} \cdot \mathrm{cm}^{-2}$ DEET (positive control) provided $97 \%$ repellency after $1 \mathrm{~h}$. ${ }^{9}$ Positive control $15 \%$ DEET (in EtOH) $=92 \%$ protection (average over trial period).

h Positive control $20 \%$ DEET (in EtOH) $=64 \%$ protection (average over trial period)

tion). In another example, 15\% eucalyptus (Eucalyptus spp.) EO and $5 \%$ vanillin provided $5 \mathrm{~h}$ of repellency against Ae. albopictus [18] and in other work involving human volunteers, clove (Syzygium aromaticum) bud EO and vanillin mixtures provided long acting repellency against adult female $C x$. pipiens pallens [151]. Thus, combinations of vanillin with plant EOs can lead to formulations which are substitutes for DEET [138,142,151].

In patents, vanillin is cited as an ingredient in mosquito repellent formulations with: Zanthoxylum armatum DC. and/or Z. piperitum DC. EOs [194], clove bud and leaf (Syzygium aromaticum), juniper berry (Juniperus communis) and/or marjoram (Origanum majorana) EOs [195], lemongrass (Cymbopogon citratus) EO/pmenthane-3,8-diol formulations [196], combinations of citronella, clove, geranium (Pelargonium graveolens), lavender (Lavandula angustifolia), patchouli [Pogostemon cablin (Blanco) Benth.] and peppermint (Mentha × piperita) EOs [197] among others.

\section{Synthetic additives in EO-containing inventions}

About $25 \%$ of all EO-containing patented repellents had at least one synthetic repellent component. Thus, DEET ( $N, N$-diethyl $m$ toluamide), the gold-standard synthetic mosquito repellent [11], was used in $10 \%$ and dimethyl (dialkyl) phthalates were cited in $5 \%$ of EO-containing patented inventions. Also, one or more synthetic pyrethroids (allethrin, cyhalothrin, deltamethrin, dimefluthrin, esbiothrin, metofluthrin, permethrin, tetramethrin and vaporthrin) were used in $10 \%$ of EO-containing mosquito repellents. It must be stressed that pyrethroids can be strong mosquitocides (toxicity), spatial mosquito repellents and mosquito irritants as was shown, for example, for permethrin in field studies [6] and $\alpha$-cypermethrin, deltamethrin, permethrin in a very re- cent publication [198]. Only about $3 \%$ of patents made use of the synthetic synergist piperonyl butoxide.

\section{Chemical Composition of EOs Used in Patented Inventions \\ $\nabla$}

Information on the major chemical components of plant EOs used in mosquito repellent inventions is presented in $\bullet$ Table 1. Among these are EOs which are concentrated sources of proven mosquito repellent monoterpenes and phenylpropanoids such as the EOs of angelica (Angelica archangelica), artemisia (Artemisia argyi), basil (Ocimum basilicum), bergamot (Citrus $\times$ bergamia), camphor (Cinnamomum camphora), cassia (Cinnamomum cassia), catnip (Nepeta cataria), chrysanthemum (Chrysanthemum indicum), cinnamon (Cinnamomum zeylanicum), citronella (Cymbopogon nardus, C. winterianus), coriander (Coriandrum sativum), cypress (Cupressus sempervirens), dill (Anethum graveolens), eucalyptus (Eucalyptus spp.), geranium (Pelargonium graveolens), grapefruit (Citrus reticulata), ho leaf (Cinnamomum camphora), hyssop (Hyssopus officinalis), juniper (Juniperus communis), lavender (Lavandula angustifolia), lemon (Citrus $\times$ limon), lemon eucalyptus (Eucalyptus citriodora), lemongrass (Cymbopogon citratus), lemon tea tree (Leptospermum petersonii), lime (Citrus $\times$ aurantifolia), marjoram (Origanum majorana), may chang/litsea (Litsea cubeba), melaleuca/tea tree (Melaleuca alternifolia), mint/mentha (Mentha), orange (Citrus $\times$ sinensis), palmarosa (Cymbopogon martini), curl leaf parsley (Petroselinum crispum), pepper (Piper nigrum), pine (Pinus sylvestris), rose (Rosa $\times$ damascena, $R . \times$ centifolia), rosemary (Rosmarinus officinalis), salvia/sage (Salvia spp.), sour (bitter) orange (Citrus $\times$ aurantium), 
spearmint (Mentha spicata), thyme (Thymus vulgaris), verbena (Lippia triphylla) and wintergreen (Gaultheria procumbens). In these EOs, proven mosquito repellent volatile components camphor, 1,8-cineole, citronellol, eugenol, geranial, geraniol, limonene, linalool, myrcene, $\alpha$ and $\beta$-pinenes, $\gamma$-terpinene, terpinen4 -ol and $\alpha$-terpineol are well represented among the major components ( $\bigcirc$ Table 4 ).

\section{Chemical composition of glyceridic oils}

\section{used in patented EO-containing inventions}

Glyceridic plant oils are important components of EO-containing mosquito repellent formulations not only for their carrier properties, but because they contain trace or larger amounts of free, long-chain mono- and polyunsaturated fatty acids and derivatives of these. It has been known for some time that insect antennae are highly sensitive to gas-phase long-chain fatty acids. For example, Hwang et al. [199] showed that gravid $C x$. quinquefasciatus Say in an olfactometer in contact with room temperature vapors of $\mathrm{C}_{14}-\mathrm{C}_{24}$ mono-, di- and polyunsaturated fatty acids were significantly repelled. These authors also demonstrated that fatty acids having at least one $Z$-configuration olefin bond (analogous saturated and $E$-configuration fatty acids were less repellent or inactive) were especially effective repellents. One of the most repellent fatty acids was oleic acid (9Z-olefin) which is a common free fatty acid in vegetable oils whose 18 carbon chain was considered to be optimal within the group of fatty acids studied [199]. Independently, female Ae. aegypti were found to be moderately repelled by oleic acid as compared to DEET in a human-bait assay [145]. Thus, free, long-chain, unsaturated fatty acids which are present in glyceridic oils are sufficiently volatile to be mosquito repellent substances in formulations containing plant EOs. This is especially relevant given claims in several patents of the mosquito repellent effects of olive (Olea europaea L.), sesame (Sesamum indicum L.), mustard (Brassica L. spp.), soybean [Glycine $\max$ (L.) Merr.] and other oils (for examples, see [200] or [201]).

\section{Mosquito repellent major chemical components of EOs}

Among the more widely distributed mosquito repellent major chemical components of EOs used in patented inventions are the cyclic and noncyclic monoterpenes limonene, $\alpha$-pinene, 1,8-cineole and linalool ( $\odot$ Table 4$)$. These are major components of, respectively, 28, 22 [including limonene-containing perilla (Perilla frutescens) oil], 22 and 21\% [including linalool-containing evening primrose (Oenothera biennis) oil] of the EOs most used in patented repellent inventions ( $\bullet$ Table $\mathbf{1}$ ).

EOs in patented mosquito repellent inventions are composed of a number of chemical components which individually exhibit important mosquito repellency, deterrency and inhibitory effects ( $\triangle$ Table 1 and Table 4). For example, $\alpha$-bisabolol and $\alpha$-santalol provided $3 \mathrm{~h}$ of high spatial repellency and contact repellency equivalent to DEET against female Ae. aegypti while E-nerolidol exhibited good spatial repellency for $3 \mathrm{~h}$ and less contact repellency than DEET [181]. Also, the following substances singly exhibited good repellency against the mosquito species indicated: carvacrol $\left(\mathrm{RC}_{50}=2.4 \times 10^{-4} \mathrm{mg} \cdot \mathrm{cm}^{-2}\right.$, female An. gambiae $)$ [183], cinnamaldehyde $\left(0.051 \mathrm{mg} \cdot \mathrm{cm}^{-2}\right.$ against female Aedes aegypti, repellency comparable to DEET) [184], citronellal $\left(\mathrm{RD}_{50}=\right.$ $\left.2.2 \times 10^{-4} \mathrm{mg} \cdot \mathrm{cm}^{-2}\right), p$-cymene $\left(\mathrm{RD}_{50}=1.0 \times 10^{-5} \mathrm{mg} \cdot \mathrm{cm}^{-2}\right)$ and cis-verbenol $\left(\mathrm{RD}_{50}=7.5 \times 10^{-5} \mathrm{mg} \cdot \mathrm{cm}^{-2}\right)$ against female An. gambiae [163], geranial $\left(0.2 \mathrm{mg} \cdot \mathrm{cm}^{-2}\right.$, reduces blood-sucking by $C x$. pipiens pallens and $C x$. pipiens quinquefasciatus over $3 \mathrm{~h}$ ). The fol- lowing EO components provided reasonable repellency at $c a$. $2 \mu \mathrm{g} \cdot \mathrm{cm}^{-2}$ against adult Ae. aegypti and Ae. albopictus: 3-carene, limonene, $\alpha$-terpinene, $\gamma$-terpinene, terpinen- 4 -ol and terpinolene [189].

Several interesting isolated repellent substances are described in patented EO-containing products ( 0 Table 3 ). For example, hinokitiol-containing polyester non-woven fabric and hinokitiolcoated polyester foot band are said to provide $100 \%$ repellency against mosquitoes and hinokitiol from hibawood (Thujopsis dolabrata) EO (and other sources) is an important natural repellent [150]. Another example is the isolation of edulan from ginkgo (Ginkgo biloba) EO and the repellent activity of this compound and derivatives against Ae. albopictus are described in a patent in which it is also claimed that these compounds are safe to humans [149]. The mosquito repellent natural substance $d$-8-acetoxycarvotanacetone was isolated from Mentha haplocalyx Briq. [157]. Also, several Lippia spp. EOs were cited in patents [e.g., L. sidoides and L. javanica (wild verbena or lippie oil)] and are important sources of the mosquito repellent compounds perrilic acid and perillaldehyde $[163,164]$ (O Table 3). The latter compound is a component of perilla (Perilla frutescens) oil and exhibited good repellency $\left(\mathrm{RD}_{50}=3.2 \times 10^{-4} \mathrm{mg} \cdot \mathrm{cm}^{-2}\right)$ against female $A$. gambiae [163] ( $\odot$ Table 4). In another patented invention, garlic (Allium sativum) EO and isolated component chemicals of garlic EO were tested for repellency against mosquitoes. More than a dozen allyl sulfide, allyl disulfide and allyl polysulfide components of garlic EO applied to human skin were found to deter Ae. aegypti, An. gambiae and $C x$. quinquefasciatus landing and blood feeding [202].

\section{Geraniol}

Geraniol is a major component of $16 \%$ of the more used EOs in patented inventions ( $\bullet$ Table $\mathbf{1}$ ) and its mosquito repellency has been studied. As an isolated chemical, it exhibited good repellency on human skin in the lab [163] and reversible spatial repellency/protection from bites [188]. A 25\% formulation of this substance was the basis for a commercial product which exhibited effective repellency in the lab $[93,167,169]$ but was less effective as compared to other products at repelling mosquitoes according to an early field study [143]. In a recent field study, a 25\% geraniol and lemongrass (Cymbopogon citratus) composition offered superior protection against the bites of Ae. atlanticus and Ae. mitchellae $(4 \mathrm{~h})$ than repellent formulations based on $12 \%$ EOs $(1 \mathrm{~h})$ and EOs, benzophenone-3, octinoxate and octisalate mixture (1.5 h) [147].

\section{p-Menthane-3,8-diol}

The mosquito repellency of the component of Eucalyptus spp. EOs, $p$-menthane-3,8-diol (PMD), is firmly established $[8,143$, 178]. As a repellent additive in formulations, $15-16 \% \mathrm{PMD} / \mathrm{lem}-$ ongrass formulations provided 5-6 h of excellent repellency (9599\%) against Anopheles and Aedes spp. [153]. Indeed, in a U.S. Dept. of Agriculture study, 26\% PMD-containing product was more repellent in the lab to Ae. albopictus, Cx. nigripalpus and Ae.triseriatus than synthetic products based on $10 \%$ KBR3023, $7.5 \%$ IR3535, 15\% and 7\% DEET, and 7 natural product-based repellents based on $2 \%$ soybean oil, $10 \%$ citronella EO, neem oil, $25 \%$ geraniol, etc. [169]. 


\section{Mosquito repellent minor components of EOs}

Some minor or lower concentration components of EOs are worth mentioning because they exhibit significant mosquito repellency. For example, citral (geranial + neral) and fenchyl alcohol are minor components of citronella (Cymbopogon nardus, C. winterianus) and rose (Rosa damascena) EOs, respectively, and exhibit moderate repellency to female An. gambiae $\left(\mathrm{RD}_{50}=1.3 \times 10^{-3}\right.$ and $1.4 \times 10^{-3} \mathrm{mg} \cdot \mathrm{cm}^{-2}$, respectively) [163]. Also, linalool oxide, a minor component of lemon eucalyptus (E. citriodora) EO was found to be repellent $\left(\mathrm{RC}_{50}=6.5 \times 10^{-4} \mathrm{mg} \cdot \mathrm{cm}^{-2}\right)$ to female $A n$. gambiae [183] and Tripathi et al. [161] found that the peppermint (Mentha $\times$ piperita) EO component piperitone oxide was highly repellent to adult An. stephensi. In other works, farnesol [a component of chamomile, jasmine and rose (Rosa damascena) EOs], elemol (a component of catnip, citronella and hyssop EOs) and hedycaryol (a component of black pepper EO) exhibited 69, 89 and $95 \%$ spatial repellency over $180 \mathrm{~min}$ to adult female Ae. aegypti and avoidance frequency (contact repellency) greater than or equal to that of DEET [181]. Cinnamyl alcohol, a minor constituent of cassia (Cinnamomum cassia) EO, exhibits less repellency to female Ae. aegypti than the major component, cinnamaldehyde, but still this repellency is significant (at $0.051 \mathrm{mg} \cdot \mathrm{cm}^{-2}$, $86 \%$ protection after $30 \mathrm{~min}$ ) and worth mentioning here [184]. Also, a minor component of EO of catmint (Nepeta L. spp.) EOs [28], dihydronepetalactone, exhibits important repellency against arthropods, including mosquitoes [203]. Citronellyl acetate is a minor component of eucalyptus (Eucalyptus spp.) [165], lemon eucalyptus (E. citriodora) [66], rose (Rosa damascena) [87] and tarragon (Artemisia dracunculus) [99] EOs and is a feeding deterrent/repellent and mosquito spatial repellent/inhibitor. Also, the minor component of salvia/sage EO [92], hydroxy-pcymene, is both a feeding deterrent/repellent and mosquito contact repellent/deterrent [186]. Lastly, isoeugenol (a component of clove EO) was found to be highly repellent to female $C x$. pipiens pallens [151].

\section{Synthetic EOs: Additive Effects/Synergism versus Suppression/Dilution \\ $\nabla$}

In some cases, patented formulations in effect improve upon the natural repellency of an essential oil by mimicking or synthesizing an oil which ideally contains components which together contribute to the repellent effect and eliminates those which counteract (attract mosquitoes), make no contribution or suppress the repellency of other components. Work done by Odalo et al. [183] nicely illustrates this process. An initial observation was that major components of 6 EOs when tested singly were less repellent than the natural EOs in which these components are found. Synthetic EOs were prepared by mixing pure major components in the same proportion in which they occur in the natural EOs. Repellencies of synthetic EOs ranged from comparable to up to three times the activity of the corresponding natural EOs against $A n$. gambiae in the human-bait test based on $\mathrm{RC}_{75}$ values [183]. The activity of synthetic EOs substantiates the additive and/or synergistic nature of the interaction of blended EO components (and also suppressive or diluting/repellency diminishing effects of nonactive components). The same principles of addition/synergism and suppression/dilution are operational in the process of formulating EOs and isolated components into patented repellent inventions.

\section{Enantiomeric Composition of EOs \\ $\nabla$}

Scientific (and patent) literature on the composition of EOs is often based on non-chiral column gas chromatography-mass spectrometry (GC-MS) and compound retention time/index analysis. Thus, information is not systematically available on the enantiomeric purity of the EO components in $\triangle$ Table 1. Enantiospecificity in mosquito repellency is an important issue. For example, Gu et al. [189] found that commercial $R$-(-)-terpinen-4-ol exhibited $>90 \%$ repellency against Ae. aegypti and Ae. albopictus adults at a concentration of $1.92 \mu \mathrm{g} \cdot \mathrm{cm}^{-2}$ in a test lasting $1 \mathrm{~h}$. S(+)-terpinen-4-ol of high enantiomeric purity is found in lavender (Lavandula angustifolia) EOs [204]. No mosquito repellency data were found in the literature for $S$-(+)-terpinen-4-ol. In principle, enantiomers may not be equally repellent to mosquitoes and their organoleptic and other properties (toxic, allergic, etc.) are not equally desirable for use as repellents. More research is needed on the comparative mosquito repellency of enantiomerically pure EO components such as $S$-(+)-terpinen-4-ol and $R$ (-)-terpinen-4-ol against different mosquito species.

\section{Allergenicity of EO Chemical Components}

$\nabla$

Limonene, benzyl alcohol, linalool, citronellol, geraniol, citral, anisyl alcohol, cinnamaldehyde, eugenol, isoeugenol, coumarin, farnesol, benzyl benzoate, benzyl salicylate among other volatile components are known allergens. As described above, these components are major or minor components of EOs used in repellent inventions ( $\bullet$ Table 1 and references cited therein). These and other volatile allergens are easily detected by GC-MS and are controlled in the European Union and elsewhere.

\section{Conclusion}

Patents on plant EO and volatile component-containing mosquito repellent inventions make use of scientifically substantiated claims to repellency to mosquitoes based on lab and field experiences. Our experience is that mosquito repellents and other insect control products, must be evaluated in the environments and settings in which they are to be used. Repellents must be developed based on plant oils and isolated chemical components by targeting Aedes, Anopheles, Culex and other mosquito species which are found locally and regionally. Repellency approaches should be multipronged and make use of sprays, fumigants, paints and varnishes, incense, candles, etc. in domestic settings, fumigation and spraying in outdoor settings and topical repellents, clothes made of repellent fabrics, repellent wristbands among other available products for individual protection.

\section{Acknowledgements \\ $\nabla$}

The authors are grateful to Joanne Bero and Joëlle Quetin-Leclercq for the invitation for this review. Our thanks also go to the anonymous referee for many invaluable corrections and suggestions. The authors are thankful for grants and/or scholarships received from Brazilian agencies MCT/INPA, CNPq 561559/2008-2 and 555.669/2009-2 (Brazilian Malaria Network), CNPq Bionorte Network grant 2009, FAPERN. 


\section{References}

1 WHO Media Centre. Malaria. World Health Organization (WHO) Media Centre. Available at http://www.who.int/mediacentre/factsheets/ fs094/en/. Accessed September 26, 2010.

2 WHO Media Centre. Dengue. World Health Organization (WHO) Media Centre. Available at http://www.who.int/mediacentre/factsheets/ fs117/en/. Accessed September 26, 2010

3 Burfield T, Reekie SL. Mosquitoes, malaria and essential oils. Int J Aromather 2005; 15: 30-41

4 WHO Media Centre. Filariasis. World Health Organization (WHO) Media Centre. Available at http://www.who.int/topics/filariasis/en/. Accessed September 26, 2010

5 WHO Media Centre. Yellow Fever. World Health Organization (WHO) Media Centre. Avaliable at http://www.who.int/mediacentre/factsheets/fs100/en/. Accessed September 26, 2010

6 Brown M, Hebert AA. Insect repellents: an overview. J Am Acad Dermatol 1997; 36: 243-249

7 Nerio LS, Olivero-Verbel J, Stashenko E. Repellent activity of essential oils: a review. Bioresour Technol 2010; 101: 372-378

8 Batish DR, Singh HP, Kohli RK, Kaur S. Eucalyptus essential oil as a natural pesticide. For Ecol Manage 2008; 256: 2166-2174

9 EPA. US Environmental Protection Agency. Notice to manufacturers, formulators, producers and registrants of pesticide products on minimum risk pesticides exempted under FIFRA Section 25(b) Pesticide Registration (PR). Notice 2000-6, 2000. Labeling Unit, Registration Division (7505C). Washington; Office of Pesticide Programs, EPA. 2000. Available from: http://www.epa.gov/pesticides/biopesticides/ingredients/ factsheets/factsheet_plant-oils.htm. Accessed September 26, 2010

10 Bakkali F, Averbeck S, Averbeck D, Zhiri A, Idaomar M. Cytotoxicity and gene induction by some essential oils in the yeast Saccharomyces cerevisiae. Mutat Res 2005; 585: 1-13

11 SciFinder Scholar. Chemical Abstracts Service - A division of the American Chemical Society. Available at http://www.cas.org/products/sfacad/index.html. Accessed September 28, 2010

12 Tropicos.org. Missouri botanical garden. Available at http://www.tropicos.org. Accessed November 30, 2010

13 Rout PK, Rao YR, Jena KS, Sahoo D, Mishra BC. Extraction and composition of the essential oil of ambrette (Abelmoschus moschtus) seeds. J Essent Oil Res 2004; 16: 35-37

14 Rout PK, Barik KC, Jena KS, Sahoo D, Rao YR. A novel process for the extraction of fragrance components from ambrette (Hibiscus abelmoschus L.) seeds. Org Proc Res Dev 2002; 6: 401-404

15 Nivinskiene 0 , Butkiene R, Mockute D. Changes in the chemical composition of essential oil of Angelica archangelica L. roots during storage. Chemija (Vilnius) 2003; 14: 52-56

16 Wu M, Sun X, Dai Y, Guo F, Huang L, Liang Y. Determination of constituents of essential oil from Angelica sinensis by gas chromatographymass spectrometry. J Central South Univ Technol 2005; 12: 430-436

17 Arslan N, Gürbüz B, Sarihan EO, Bayrak A, Gümüsçü A. Variation in essential oil content and composition in Turkish anise (Pimpinella anisum L.) populations. Turkish J Agric For 2004; 28: 173-177

18 Wenqiang G, Shufen L, Ruixiang Y, Yanfeng H. Comparison of composition and antifungal activity of Artemisia argyi Lévl. et Vant inflorescence essential oil extracted by hydrodistillation and supercritical carbon dioxide. Nat Prod Res 2006; 20: 992-998

19 Zheng X, Deng C, Song G, Hu Y. Comparison of essential oil composition of Artemisia argyi leaves at different collection times by headspace solid-phase microextraction and gas chromatography-mass spectrometry. Cromatographia 2004; 59: 729-732

20 Inouye S, Uchida $K$, Abe $S$. Volatile composition and vapour activity against Trichophyton mentagrophytes of 36 aromatic herbs cultivated in Chichibu district in Japan. Intl J Aromather 2006; 16: 159-168

21 Viña A, Murillo E. Essential oil composition from twelve varieties of basil (Ocimum spp.) grown in Colombia. J Braz Chem Soc 2003; 14: 744749

22 Chalchat J-C, Özcan MM. Comparative essential oil composition of flowers, leaves and stems of basil (Ocimum basilicum L.) used as herb. Food Chem 2008; 110: 501-503

23 Sangun MK, Aydin E, Timur M, Karadeniz H, Caliskan M, Ozkan A. Comparison of chemical composition of the essential oil of Laurus nobilis $\mathrm{L}$. leaves and fruits from different regions of Hatay, Turkey. J Environment Biol 2007; 28: 731-733
24 Cosimi S, Rossi E, Cioni PL, Canale A. Bioactivity and qualitative analysis of some essential oils from Mediterranean plants against stored-product pests: evaluation of repellency against Sitophilus zeamais Motschulsky, Cryptolestes ferrugineus (Stephens) and Tenebrio molitor (L.). J Stored Prod Res 2009; 45: 125-132

25 Wang $R$, Wang $R$, Yang $B$. Extraction of essential oils from five cinnamon leaves and identification of their volatile compound compositions. Innovative Food Sci Emerg Technol 2009; 10: 289-292

$26 \mathrm{Du} \mathrm{H}, \mathrm{Li} \mathrm{H}$. Antioxidant effect of cassia essential oil on deep-fried beef during the frying process. Meat Sci 2008; 78: 461-468

27 Gilani AH, Shaha AJ, Zubair A, Khalid S, Kiani J, Ahmed A, Rasheed M, Ahmad VU. Chemical composition and mechanisms underlying the spasmolytic and bronchodilatory properties of the essential oil of Nepeta cataria L. J Ethnopharmacol 2009; 121: 405-411

28 Heuskin S, Godin B, Leroy P, Capella $Q$ Wathelet J-P, Verheggen F, Haubruge E, Lognay $G$. Fast gas chromatography characterisation of purified semiochemicals from essential oils of Matricaria chamomilla L. (Asteraceae) and Nepeta cataria L. (Lamiaceae). J Chromatogr A 2009; 1216: 2768-2775

29 Burfield T. Cedarwood oils. Part 1. Aromather Times 2002; 1: 14-15

30 Lawrence BM. Progress in essential oils. Perfumer Flavorist 2005; 30 : 56-67

31 Wu L-Y, Gao H-Z, Wang X-L, Ye J-H, Lu J-L, Liang Y-R. Analysis of chemical composition of Chrysanthemum indicum flowers by GC/MS and HPLC. J Med Plant Res 2010; 4: 421-426

32 Zhu S, Yang Y, Yu H, Ying Y, Zou G. Chemical composition and antimicrobial activity of the essential oils of Chrysanthemum indicum. J Ethnopharmacol 2005; 96: 151-158

33 Fichi G, Flamini G, Zaralli LJ, Perrucci S. Efficacy of an essential oil of Cinnamomum zeylanicum against Psoroptes cuniculi. Phytomedicine 2007; 14: 227-231

34 Singh G, Maurya S, DeLampasona MP, Catalan CAN. A comparison of chemical, antioxidant and antimicrobial studies of cinnamon leaf and bark volatile oils, oleoresins and their constituents. Food Chem Toxicol 2007: 45: 1650-1661

35 Nakahara K, Alzoreky NS, Yoshihashi T, Nguyen HTT, Trakoontivakorn G. Chemical composition and antifungal activity of essential oil from Cymbopogon nardus (citronella grass). Jpn Intl Res Center Agric Sci 2003; 37: 249-252

36 Sethi ML, Taneja SC, Dhar KL, Atal CK. Chemical investigations on the essential oil of Burmese citronella. Indian Perfumer 1979; 23: 167-171

37 Guan W, Li S, Yan R, Tang S, Quan C. Comparison of essential oils of clove buds extracted with supercritical carbon dioxide and other three traditional extraction methods. Food Chem 2007; 101: 1558-1564

38 Msaada K, Taarit MB, Hosni K, Hammami M, Marzouk B. Regional and maturational effects on essential oils yields and composition of coriander (Coriandrum sativum L.) fruits. Sci Hortic 2009; 122: 116-124

39 Zheljazkova VD, Pickett KM, Caldwell CD, Pincock JA, Roberts JC, Mapplebeck $L$. Cultivar and sowing date effects on seed yield and oil composition of coriander in Atlantic Canada. Indian Crops Prod 2008; 28: 88-94

40 Tapondjou AL, Adler C, Fontem DA, Bouda H, Reichmuth C. Bioactivities of cymol and essential oils of Cupressus sempervirens and Eucalyptus saligna against Sitophilus zeamais Motschulsky and Tribolium confusum du Val. J Stored Prod Res 2005; 41: 91-102

41 Sacchetti OG, Maietti S, Muzzoli M, Scaglianti M, Manfredini S, Radice M, Bruni R. Comparative evaluation of 11 essential oils of different origin as functional antioxidants, antiradicals and antimicrobials in foods. Food Chem 2005; 91: 621-632

42 Bailer J, Aichinger T, Hackl G, de Hueber K, Dachler M. Essential oil content and composition in commercially available dill cultivars in comparison to caraway. Indian Crops Prod 2001; 14: 229-239

43 Callan NW, Johnson DL, Westcott MP, Welty LE. Herb and oil composition of dill (Anethum graveolens L.): Effects of crop maturity and plant density. Indian Crops Prod 2007; 25: 282-287

44 Kimbaris AC, Siatis NG, Daferera DJ, Tarantilis PA, Pappas CS, Polissiou $M G$. Comparison of distillation and ultrasound-assisted extraction methods for the isolation of sensitive aroma compounds from garlic (Allium sativum). Ultrason Sonochem 2006; 13: 54-60

45 Shaath NA, Flores FB, Ositian M, Aal MA-E. The essential oil of Allium sativum L., Liliaceae (garlic). In: Charalambous G, editor. Food flavors: generation, analysis and process influence. Amsterdam: Elsevier Science; 1995: 2025-2037 
46 Seo S-M, Kim J, Lee S-G, Shin C-H, Shin S-C, Park I-K. Fumigant antitermitic activity of plant essential oils and components from ajowan ( $\mathrm{Tra}$ chyspermum ammi), allspice (Pimenta dioica), caraway (Carum carvi), dill (Anethum graveolens), geranium (Pelargonium graveolens), and litsea (Litsea cubeba) oils against Japanese termite (Reticulitermes speratus Kolbe). J Agric Food Chem 2009; 57: 6596-6602

47 Singh G, Kapoor IPS, Singh P, de Heluani CS, de Lampasona MP, Catalan CAN. Chemistry, antioxidant and antimicrobial investigations on essential oil and oleoresins of Zingiber officinale. Food Chem Toxicol 2008; 46: 3295-3302

48 Sakamura F. Changes in volatile constituents of Zingiber officinale rhizomes during storage and cultivation. Phytochemistry 1987; 26: 2207-2212

49 Chutia M, Deka Bhuyan P, Pathak MG, Sarma TC, Boruah P. Antifungal activity and chemical composition of Citrus reticulata Blanco essential oil against phytopathogens from North East India. LWT - Food Sci Technol 2009; 42: 777-778

50 Bates RB, Slagel RC. Terpenoids. VI. $\beta$-Bulnesene, $\alpha$-guaiene, $\beta$-patchoulene, and guaioxide in essential oils. Chem Ind 1962; 1715-1716

51 Yatagai M, Sat T, Takahashi T. Terpenes of leaf oils from Cupressaceae. Biochem Syst Ecol 1985; 13: 377-385

52 Burfield T. Cedarwood oils - part 2. Aromather Times 2003; 1: 14-16

53 Nozoe T, Yasue A, Yamane $K$. On the acidic constituents of the essential oil of Thujopsis dolabrata. Occurrence of $\alpha$-thujaplicin. Proc Jpn Acad 1951; 27: 15-17

54 Zhang G, Chen C, Chen Z, Chen R, Lin X. Analysis of principle component and chemistry type of essential oil from Cinnamomum camphora leaf in Fujian province. Zhiwu Ziyuan Yu Huanjing Xuebao 2008; 17: 24-27

55 Nguyen XD, Trinh DC, Nguyen BT, Pham VK, Leclerco PA. Constituents of the leaf oil of Cinnamomum camphora Nees et Eberm from Hue. Tap Chi Hoa Hoc 1994; 32: 64-66

56 Kazazi H, Rezaei K, Ghotb-Sharif SJ, Emam-Djomeh Z, Yamini Y. Supercriticial fluid extraction of flavors and fragrances from Hyssopus officinalis L. cultivated in Iran. Food Chem 2007; 105: 805-811

57 Langa E, Cacho J, Palavra AMF, Burillo J, Mainar AM, Urieta JS. The evolution of hyssop oil composition in the supercritical extraction curve. J Supercrit Fluids 2009; 49: 37-44

58 Chalchat J-C, Adamovic D, Gorunovic MS. Composition of oils of three cultivated forms of Hyssopus officinalis endemic in Yugoslavia: f. albus Alef., f. cyaneus Alef. and f. ruber Mill. J Essent Oil Res 2001; 13: 419421

59 Rath CC, Devi S, Dash SK, Mishra RK. Antibacterial potential assessment of jasmine essential oil against E. coli. Indian J Pharm Sci 2008; 70: 238-241

60 Sandeep, Paarakh PM. Jasminum grandiflorum Linn (Chameli): ethnobotany, phytochemistry and pharmacology - a review. Pharmacol Online 2009; 2: 586-595

61 Angioni A, Barra A, Russo MT, Coroneo V, Dessi S, Cabras P. Chemical composition of the essential oils of Juniperus from ripe and unripe berries and leaves and their antimicrobial activity. J Agric Food Chem 2003; 51: 3073-3078

62 Al-Reza SM, Rahman A, Kang SC. Chemical composition and inhibitory effect of essential oil and organic extracts of Cestrum nocturnum L. on food-borne pathogens. Int J Food Sci Technol 2009; 44: 1176-1182

63 Salehi FARP, Heydari R, Ebrahimi SN, Haddad PR. Hydrodistillationheadspace solvent microextraction, a new method for analysis of the essential oil components of Lavandula angustifolia Mill. J Chromatogr A 2005; 1098: 14-18

64 Daferera DJ, Ziogas BN, Polissiou MG. GC-MS analysis of essential oils from some Greek aromatic plants and their fungitoxicity on Penicillium digitatum. J Agric Food Chem 2000; 48: 2576-2581

65 Flamini G, Tebano M, Cioni PL. Volatiles emission patterns of different plant organs and pollen of Citrus limon. Anal Chim Acta 2007; 589: $120-124$

66 El-Zalabani SM, Koheil MM, Meselhy KM, El-Gizawy HA, Sleem AA. Effect of seasonal variation on composition and bioactivities of the essential oil of Eucalyptus citriodora Hook. grown in Egypt. Egyptian J Biomed Sci 2007; 24: 260-276

67 Brophy JJ, Goldsack RJ, Punruckvong A, Bean AR, Forster PI, Lepschi BJ, Doran JC, Rozefelds AC. Leaf essential oils of the genus Leptospermum (Myrtaceae) in eastern Australia. Part 7. Leptospermum petersonii, L. liversidgei and allies. Flav Fragr J 2000; 15: 342-351
68 Patil JR, Jayaprakasha GK, Murthy KNC, Tichy SE, Chetti MB, Patil BS. Apoptosis-mediated proliferation inhibition of human colon cancer cells by volatile principles of Citrus aurantifolia. Food Chem 2009; 114: 1351-1358

69 Douglas MH, van Klink JW, Smallfield BM, Perry NB, Anderson RE, Johnstone, Weavers RT. Essential oils from New Zealand manuka: triketone and other chemotypes of Leptospermum scoparium. Phytochemistry 2004; 65: 1255-1264

70 Perry NB, Brennan NJ, Van Klink JW, Harris W, Douglas MH, McGimpsey $J A$, Smallfield BM, Anderson RE. Essential oils from New Zealand manuka and kanuka: chemotaxonomy of Leptospermum. Phytochemistry 1997; 44: 1485-1494

71 Vági E, Simándi B, Suhajda A, Héthelyi E. Essential oil composition and antimicrobial activity of Origanum majorana L. extracts obtained with ethyl alcohol and supercritical carbon dioxide. Food Res Int 2005; 38: 51-57

72 Vera RR, Chane-Ming J. Chemical composition of the essential oil of marjoram (Origanum majorana L.) from Reunion Island. Food Chem 1999; 66: 143-145

73 Lalko J, Api AM. Investigation of the dermal sensitization potential of various essential oils in the local lymph node assay. Food Chem Toxicol 2006; 44: 739-746

74 Lawrence BM. Progress in essential oils. Perfumer Flavorist 2006; 31: 54-57

75 Brophy IJ, Davies NW, Southwell IA, Stiff IA, Williams LR. Gas chromatographic quality control for oil of melaleuca terpinen-4-ol type (Australian tea tree). J Agric Food Chem 1989; 37: 1330-1335

76 Marengo E, Baiocchi C, Gennaro MC, Bertolo PL, Lanteri S, Garrone W. Classification of essential mint oils of different geographic origin by applying pattern recognition methods to gas chromatographic data. Chemometrics Intell Lab Syst 1991; 11: 75-88

77 Tao N-G, Liu Y-J, Zhang M-L. Chemical composition and antimicrobial activities of essential oil from the peel of bingtang sweet orange (Citrus sinensis Osbeck). Int J Food Sci Technol 2009; 44: 1281-1285

78 Raina VK, Srivastava SK, Aggarwal KK, Syamasundar KV, Khanuja SPS. Essential oil composition of Cymbopogon martinii from different places in India. Flav Fragr 2003; 18: 312-315

79 Petropoulos SA, Daferera D, Polissiou MG, Passam HC. Effect of nitrogenapplication rate on the biomass, concentration, and composition of essential oils in the leaves and roots of three types of parsley. J Plant Nutr Soil Sci 2009; 172: 210-215

80 Nikiforov A, Jirovetz L, Buchbauer G, Raverdino V. GC-FTIR and GC-MS in odour analysis of essential oils. Microchim Acta 2005; 95: 193-198

81 Orav A, Stulova I, Kailas T, Müürisepp M. Effect of storage on the essential oil composition of Piper nigrum L. fruits of different ripening states. J Agric Food Chem 2004; 52: 2582-2586

82 Kapoor IPS, Singh B, Singh G, De Heluani CS, De Lampasona MP, Catalan CAN. Chemistry and in vitro antioxidant activity of volatile oil and oleoresins of black pepper (Piper nigrum). J Agric Food Chem 2009; 57: $5358-5364$

83 Kowalski R, Wawrzykowski J. Essential oils analysis in dried materials and granulates obtained from Thymus vulgaris L., Salvia officinalis L., Mentha piperita L. and Chamomilla recutita L. Essential oil analysis in dried materials and granulates. Flav Fragr 2009; 24: 31-35

84 Aziz EE, Craker LE. Essential oil constituents of peppermint, pennyroyal, and apple mint grown in a desert agrosystem. J Herbs Spices Med Plants 2009; 15: 361-367

85 Judzentiene A, Kupcinskiene E. Chemical composition on essential oils from needles of Pinus sylvestris L. grown in northern Lithuania. J Essent Oil Res 2008; 20: 26-29

86 Ustun O, Sezik E, Kurkcuoglu M, Baser KHC. Study of the essential oil composition of Pinus sylvestris from Turkey. Chem Nat Comp 2006; 42: $26-31$

87 Almasirad A, Amanzadeh Y, Taheri A, Iranshahi M. Composition of a historical rose oil sample (Rosa damascena Mill., Rosaceae). J Essent Oil Res 2007; 19: 110-112

88 Gillij YG, Gleiser RM, Zygadlo JA. Mosquito repellent activity of essential oils of aromatic plants growing in Argentina. Bioresour Technol 2008; 99: $2507-2515$

89 Geneva MP, Stancheva IV, Boychinova MM, Mincheva NH, Yonova PA. Effects of foliar fertilization and arbuscular mycorrhizal colonization on Salvia officinalis L. growth, antioxidant capacity, and essential oil composition. J Sci Food Agric 2010; 90: 696-702 
90 Kamatou GPP, Makunga NP, Ramogola WPN, Viljoen AM. South African Salvia species: a review of biological activities and phytochemistry. J Ethnopharmacol 2008; 119: 664-672

91 Loizzo MR, Menichini F, Tundis R, Bonesi M, Nadjafi F, Saab AM, Frega NG, Menichini F. Comparative chemical composition and antiproliferative activity of aerial parts of Salvia lerifolia Benth. and Salvia acetabulosa L. essential oils against human tumor cell in vitro models. J Med Food 2010; 13: 62-69

92 Cardile V, Russo A, Formisano C, Rigano D, Senatore F, Arnold NA, Piozzi F. Essential oils of Salvia bracteata and Salvia rubifolia from Lebanon: chemical composition, antimicrobial activity and inhibitory effect on human melanoma cells. J Ethnopharmacol 2009; 126: 265-272

93 Jones CG, Plummer JA, Barbour EL. Non-destructive sampling of Indian sandalwood (Santalum album L.) for oil content and composition. J Essent Oil Res 2007; 19: 157-164

94 Lawrence BM. Progress in essential oils. Perfumer Flavorist 2005; 30: 56-67

95 Kiran U, Patra DD. Influence of natural essential oils and their byproducts as nitrification retarders in regulating nitrogen utilization for Japanese mint in sandy loam soils of subtropical central India. Agric Ecosyst Environ 2003; 94: 237-245

96 Wang Z, Wang L, Li T, Zhou X, Ding L, Yu Y, Yu A, Zhang H. Rapid analysis of the essential oils from dried Illicium verum Hook. f. and Zingiber officinale Rosc. by improved solvent-free microwave extraction with three types of microwave-absorption medium. Anal Bioanal Chem 2006; 386: 1863-1868

97 Dzamic A, Sokovic M, Ristic MS, Grijic-Jovanovic S, Vukojevic J, Marin $P D$. Chemical composition and antifungal activity of Illicium verum and Eugenia caryophyllata essential oils. Chem Nat Comp 2009; 45: 259-261

98 Lawrence BM. Progress in essential oils. Perfumer Flavorist 2009; 34: 54-58

99 Khodakov GV, Kotikov IV, Pankovetskii VN. Component composition of essential oil from Artemisia abrotanum and A. dracunculus. Chem Nat Comp 2009; 45: 905-908

100 Argyropoulou C, Daferera D, Tarantilis PA, Fasseas C, Polissiou M. Chemical composition of the essential oil from leaves of Lippia citriodora H. B. K. (Verbenaceae) at two developmental stages. Biochem Syst Ecol 2007: 35: 831-837

101 Champagnat $P$, Figueredo $G$, Chalchat J-C, Carnat A-P. A study on the composition of commercial Vetiveria zizanioldes oils from different geographical origins. J Essent Oil Res 2006; 18: 416-422

102 Cu JQ Perineau F, Gaset A. Volatile components of violet leaves. Phytochemistry 1992; 31: 571-573

103 Tisserand R. Essential oil safety. Int J Aromather 1996; 7: 28-32

104 Martín C, Moure A, Martín G, Carrillo E, Domínguez H, Parajó JC. Fractional characterisation of jatropha, neem, moringa, trisperma, castor and candlenut seeds as potential feedstocks for biodiesel production in Cuba. Bioresour Technol 2010; 34: 533-538

105 Bicchi C, Cordero C, Liberto E, Sgorbini B, Rubiolo P. Headspace sampling of the volatile fraction of vegetable matrices. J Chromatogr A 2008; 1184: 220-233

106 Christie WW. The analysis of evening primrose oil. Indian Crops Prod 1999; 10: 73-83

107 Jeong JB, Ju SY, Park JH, Lee JR, Yun KW, Kwon ST, Lim J-H, Chung GY, Jeong HJ. Antioxidant activity in essential oils of Cnidium officinale makino and Ligusticum chuanxiong hort and their inhibitory effects on DNA damage and apoptosis induced by ultraviolet B in mammalian cell. Cancer Epidemiol 2009; 33: 41-46

108 Nabloussi A, Márquez-Lema M, Fernández-Martínez A, Velasco L. Novel seed oil types of Ethiopian mustard with high levels of polyunsaturated fatty acids. Indian Crops Prod 2008; 27: 359-363

109 Sidhu OP, Kumar V, Behl HM. Variability in triterpenoids (nimbin and salanin) composition of neem among different provenances of India. Indian Crops Prod 2004; 19: 69-75

110 Patumi M, d'Andria $R$, Marsilio V, Fontanazza G, Morelli G, Lanza B. Olive and olive oil quality after intensive monocone olive growing (Olea europaea L., cv. Kalamata) in different irrigation regimes. Food Chem 2002; 77: 27-34

111 Nitta M, Kobayashi H, Ohnishi-Kameyama M, Nagamine T, Yoshida M. Essential oil variation of cultivated and wild perilla analyzed by GC/ MS. Biochem Syst Ecol 2006; 34: 25-37

112 Longvah T, Deosthale YG, Kumar PU. Nutritional and short term toxicological evaluation of Perilla seed oil. Food Chem 2000; 70: 13-16
113 Koezuka Y, Honda G, Tabata M. Genetic control of the chemical composition of volatile oils in Perilla frutescens. Phytochemistry 1986; 25 : 859-863

114 Lee D-S, Lee E-S, Kim H-J, Kim S-O, Kim K. Reversed phase liquid chromatographic determination of triacylglycerol composition in sesame oils and the chemometric detection of adulteration. Anal Chim Acta 2001; 429: 321-330

115 Ribeiro APB, Grimaldi R, Gioielli LA, Gonçalves LAG. Zero trans fats from soybean oil and fully hydrogenated soybean oil: physico-chemical properties and food applications. Food Res Int 2009; 42: 401-410

116 Orban GJ, Staton JA. Insect repellent compositions based on essential oils. World Patent 2004010783; 2004

117 He J, Yang X, Wang Y, Li W, Zhao J, Feng J Zhang X. Plant-derived mosquito repellent synergist. Chinese Patent 101558769; 2009

118 Samson GB. Organic floor wash with disinfectant and mosquito repellent properties. Indian Patent 2007CH00296; 2007

119 Wang Z, Wan T, Zhang J, Liu H, Zhang X, Feng J, Zhang X. Plant-derived synergistic agent for mosquito incense and its preparation process. Chinese Patent 101558770; 2009

120 Inoue S, Hario S, Umibe H. Synergistic insect-repelling microcapsules containing toluamides and isobornyl compounds, for textiles. Japanese Patent 03148203; 1991

121 Peng X. Mosquito-repellent solution containing natural pyrethrin. Chinese Patent 1739353; 2006

122 Bit KC, Rao SR, Sen K. Synergistic insect repellent compositions containing dimethyl phthalate, allyl sulfate, and oils. Indian Patent 2003DE00243; 2007

123 Singh KSP, Kumar TA, Kumar AK, Kumar SM, Kumar SA, Raj BJ, Anju Y, Dinesh K, Sudeep T, Anirban P, Umrao BD, Mansoor A, Prakash DO. Slow-vaporizing anti-mosquito synergistic insecticidal herbal formulation comprising essential oil. Indian Patent 2008DE00607; 2010

124 Gilbert B, Teixeira DF, Pereira JFG, Silva Jr IV, Svaiter A, Oliveira Filho AM, Santos CE. Mosquito-repellent fumigant. Brazilian Patent 9800437; 2000

125 Ribas J, Carreno AM. Evaluation of the use of repellent against mosquito bite by military personnel in the Amazon Basin. An Bras Dermatol 2010: 85: 33-38

126 Erler F, Ulug I, Yalcinkaya B. Repellent activity of five essential oils against $C x$. pipiens. Fitoterapia 2006; 77: 491-494

127 Lin X. Repellent effects of plant essential oils on laboratory animals. Zhonghua Weisheng Shachong Yaoxie 2009; 15: 430-431

128 Amer A, Mehlhorn $H$. Repellency effect of forty-one essential oils against Aedes, Anopheles, and Culex mosquitoes. Parasitol Res 2006; 99: 478-490

129 Onanong $N$, Usawadee S, Napaporn U, Satit P, Apinan S, Uracha R. In vitro characterization and mosquito (Aedes aegypti) repellent activity of essential-oils-loaded nanoemulsions. AAPS Pharm Sci Technol 2009; 10: $1234-1242$

130 Drapeau J, Froehler C, Touraud D, Kroeckel U, Geier M, Rose A, Kunz W. Repellent studies with Aedes aegypti mosquitoes and human olfactory tests on 19 essential oils from Corsica, France. Flav Fragr J 2009; 24: $160-169$

131 Rudolfs $W$. Effect of chemicals upon the behavior of mosquitoes. New Jersey Agric Exp Station Bull 1930; 2: 496-520

132 Yang Y-C, Lee E-H, Lee H-S, Lee D-K, Ahn Y-J. Repellency of aromatic medicinal plant extracts and a steam distillate to Aedes aegypti. J Am Mosq Control Assoc 2004; 20: 146-149

133 Zhu J, Zeng X, Yanma LT, Oian K, Han Y, Xue S, Tucker B, Schultz G, Coats $J$, Rowley $W$, Zhang $A$. Adult repellency and larvicidal activity of five plant essential oils against mosquitoes. J Am Mosq Control Assoc 2006; 22: 515-522

134 Zhu JJ, Zeng X-P, Berkebile D, Du H-J, Tong Y, Qian K. Efficacy and safety of catnip (Nepeta cataria) as a novel filth fly repellent. Med Vet Entomol 2009; 23: 209-216

135 Curtis CF, Lines JD, Callaghan A, Hill N, Karimzad MA. The relative efficiency of repellents against mosquito vectors of disease. Med Vet Entomol 1987; 1: 109-119

136 Prajapati V, Tripathi AK, Aggarwal KK, Khanuja SPS. Insecticidal, repellent and oviposition-deterrent activity of selected essential oils against Anopheles stephensi, Aedes aegypti and $C x$. quinquefasciatus. Bioresour Technol 2005; 96: 1749-1757

137 Gibson A. Mosquito-suppression work in Canada in 1937. Ann Meet N Mosq Exterm Assoc 1938; 25: 176-185 
138 Tawatsin A, Wratten SD, Scott RR, Thavara U, Techadamrongsin Y. Repellency of volatile oils from plants against three mosquito vectors. J Vector Ecol 2001; 26: 76-82

139 Bindra RL, Agarwal KK, Shukla YN, Agarwal SK, Kumar S. Essential oil formulations as mosquito repellents in floor cleaners. Indian Perfumer 2001; 45: 269-273

140 Thorsell W, Mikiver A, Malander I, Tunon H. Efficacy of plant extracts and oils as mosquito repellents. Phytomedicine 1998; 5: 311-323

141 Makhaik M, Naik SN, Tewary DK. Evaluation of anti-mosquito properties of essential oils. J Sci Indian Res (India) 2005; 64: 129-133

142 Yang $P$, Ma Y. Repellent effect of plant essential oils against Aedes albopictus. J Vector Ecol 2005; 30: 231-234

143 Moore SJ, Lenglet A, Hill N. Field evaluation of three plant-based insect repellents against malaria vectors in Vaca Diez Province, the Bolivian Amazon. J Am Mosq Control Assoc 2002; 18: 107-110

144 Kim S-I, Chang K-S, Yang Y-C, Kim B-S, Ahn Y-J. Repellency of aerosol and cream products containing fennel oil to mosquitoes under laboratory and field conditions. Pest Manag Sci 2004; 60: 1125-1130

$145 \mathrm{Kim}$ D-H, Kim S-I, Chang K-S, Ahn Y-J. Repellent activity of constituents identified in Foeniculum vulgare fruit against Aedes aegypti (Diptera: Culicidae). J Agric Food Chem 2002; 50: 6993-6996

146 Bhuyan M, Saxena N, Rao KM. Repellent property of oil fraction of garlic, Allium sativum (Linn.). Indian J Exp Biol 1974; 12: 575-576

147 Qualls WA, Xue R-D. Field evaluation of three botanical repellents against Psorophora ferox, Aedes atlanticus, and Aedes mitchellae. J Am Mosq Control Assoc 2009; 25: 379-381

148 Osmani Z, Anees I, Naidu MB. Insect repellent creams from essential oils. Pesticides 1972; 6: 19-21

149 Matsumoto A, Matsumoto T, Yamashita M, Nitsuta I, Kobayashi M, Mesaki J, Kashiwabara T. Harmful insect repellents containing edulan derivatives. Japanese Patent 05221808; 1993

150 Kobayashi A, Mizutani T. Harmful insect-repellent foot bands and method for repelling harmful insects using them. Japanese Patent 2004051564; 2004

151 Kang S-H, Kim M-K, Seo D-K, Noh D-J, Yang J-O, Yoon C, Kim G-H. Comparative repellency of essential oils against $C x$. pipiens pallens (Diptera: Culicidae). J Korean Soc Appl Biol Chem 2009; 52: 353-359

152 Oshaghi MA, Ghalandari R, Vatandoost H, Shayeghi M, Kamalinejad M, Tourabi-Khaledi H, Abolhassani M, Hashemzadeh M. Repellent effect of extracts and essential oils of Citrus limon (Rutaceae) and Melissa officinalis (Labiatae) against main malaria vector, Anopheles stephensi (Diptera: Culicidae). Iran J Public Health 2003; 32: 47-52

153 Moore SJ, Darling ST, Sihuincha M, Padilla N, Devine GJ. A low-cost repellent for malaria vectors in the Americas: results of two field trials in Guatemala and Peru. Malar J 2007; 6: 1-6

154 Maguranyi SK, Webb CE, Mansfield S, Russell RC. Are commercially available essential oils from Australian native plants repellent to mosquitoes? J Am Mosq Control Assoc 2009; 25: 292-300

155 Molyneux WM. Mosquito and/or flea control with Leptospermum liversidgei and its essential oil. Canadian Patent 2234476; 1999

156 Tawatsin A, Asavadachanukorn P, Thavara U, Wongsinkongman P, Bansidhi J, Boonruad T, Chavalittumrong P, Soonthornchareonnon N, Komalamisra N, Mulla MS. Repellency of essential oils extracted from plants in Thailand against four mosquito vectors (Diptera:Culicidae) and oviposition deterrent effects against Aedes aegypti (Diptera:Culicidae). Southeast Asian J Trop Med Pub Health 2006; 37: 915-931

157 Ding D, Sun H. Structural elucidation of an insect repellent in the essential oil of Mentha haplocalyx Briq. Zhiwu Xuebao 1983; 25: 62-66

158 Dubey VS. An overview of geraniol biosynthesis in palmarosa (Cymbopogon martinii Roxb. var. motia) and its biological and pharmacological properties. Recent Progr Med Plants 2006; 11: 75-97

159 Trongtokit Y, Rongsriyam Y, Komalamisra N, Apiwathnasorn C. Comparative repellency of 38 essential oils against mosquito bites. Phytother Res 2005; 19: 303-309

160 Ansari MA, Vasudevan P, Tandon M, Razdan RK. Larvicidal and mosquito repellent action of peppermint (Mentha piperita) oil. Bioresour Technol 2000; 71: 267-271

161 Tripathi AK, Prajapati V, Ahmad A, Aggarwal KK, Khanuja SPS. Piperitenone oxide as toxic, repellent, and reproduction retardant toward malarial vector Anopheles stephensi (Diptera: Anophelinae). J Med Entomol 2004; 41: 691-698

162 Pavela $R$. Larvicidal property of essential oils against $C x$. quinquefasciatus Say (Diptera: Culicidae). Indian Crop Prod 2009; 30: 311-315
163 Omolo MO, Okinyo D, Ndiege IO, Lwande W, Hassanali A. Repellency of essential oils of some Kenyan plants against Anopheles gambiae. Phytochemistry 2004; 65: 2797-2802

164 Dorfling EA, Mouton I. Insect repellents obtained from Lippia comprising monoterpenes. South African Patent ZA 9505853; 1997

165 Tripathi AK, Prajapati V, Aggarwal KK, Khanuja SP, Kumar S. Repellency and toxicity of oil from Artemisia annua to certain stored-product beetles. J Econ Entomol 2000; 93: 43-47

166 Das NG, Baruah I, Talukdar PK, Das SC. Evaluation of botanicals as repellents against mosquitoes. J Vector Borne Dis 2003; 40: 49-53

167 Xue R-D, Alp A, Barnard DR. Laboratory evaluation of toxicity of 16 insect repellents in aerosol sprays to adult mosquitoes. J Am Mosq Control Assoc 2003; 19: 271-274

168 Vatandoost H, Hanafi-Bojd AA. Laboratory evaluation of 3 repellents against Anopheles stephensi in the Islamic Republic of Iran. East Mediterr Health J 2008; 14: 260-267

169 Barnard $D R$, Xue R-D. Laboratory evaluation of mosquito repellents against Aedes albopictus, Cx. nigripalpus, and Ochlerotatus triseriatus (Diptera: Culicidae). J Med Entomol 2004; 41: 726-730

170 Sharma VP, Ansari MA, Razdan RK. Mosquito repellent action of neem (Azadirachta indica) oil. J Am Mosq Control Assoc 1993; 9: 359-360

171 Sharma SK, Dua VK, Sharma VP. Field studies on the mosquito repellent action of neem oil. Southeast Asian J Trop Med Public Health 1995; 26: 180-182

172 Dua VK, Nagpal BN, Sharma VP. Repellent action of neem cream against mosquitoes. Indian J Malariol 1995; 32: 47-53

173 Valecha N, Ansari MA, Prabhu S, Razdan RK. Preliminary evaluation of safety aspects of neem oil in kerosene lamp. Indian J Malariol 1996; 33: $139-143$

174 Sharma VP, Ansari MA. Personal protection from mosquitoes (Diptera: Culicidae) by burning neem oil in kerosene. J Med Entomol 1994; 31 : 505-507

175 Mishra AK, Singh N, Sharma VP. Use of neem oil as a mosquito repellent in tribal villages of Mandla District, Madhya Pradesh. Indian J Malariol 1995; 32: 99-103

176 Fradin MS, Day JF. Comparative efficacy of insect repellents against mosquito bites. New Engl J Med 2002; 347: 13-18

177 Ritchie SA, Williams CR, Montgomery BL. Field evaluation of new mountain sandalwood mosquito sticks and new mountain sandalwood botanical repellent against mosquitoes in North Queensland, Australia. J Am Mosq Control Assoc 2006; 22: 158-160

178 Sultana S, Ali M, Ansari SH, Bagri P. The effect of physical factors on chemical composition of the essential oil of Eucalyptus citriodora Hook. leaves. J Essent Oilbearing Plants 2008; 11: 69-74

179 Noosidum A, Prabaripai A, Chareonviriyaphap T, Chandrapatya A. Excito-repellency properties of essential oils from Melaleuca leucadendron L., Litsea cubeba (Lour.) Persoon, and Litsea salicifolia (Nees) on Aedes aegypti (L.) mosquitoes. J Vector Ecol 2008; 33: 305-312

180 Choochote W, Chaithong U, Kamsuk K, Jitpakdi A, Tippawangkosol P, Tuetun B, Champakaew D, Pitasawat B. Repellent activity of selected essential oils against Aedes aegypti. Fitoterapia 2007; 78: 359-364

181 Paluch G, Justingrodnitzky J, Bartholomay L, Coats J. Quantitative structure-activity relationship of botanical sesquiterpenes: spatial and contact repellency to the yellow fever mosquito, Aedes aegypti. J Agric Food Chem 2009; 57: 7618-7625

182 Hwang YS, Wu KH, Kumamoto J, Axelrod H, Mulla MS. Isolation and identification of mosquito repellents in Artemisia vulgaris. J Chem Ecol 1985; 11: 1297-1306

183 Odalo JO, Omolo MO, Malebo H, Angira J, Njeru PM, Ndiege IO, Hassanali $A$. Repellency of essential oils of some plants from the Kenyan coast against Anopheles gambiae. Acta Trop 2005; 95: 210-218

184 Chang K-S, Tak J-H, Kim S-I, Lee W-J, Ahn Y-J. Repellency of Cinnamomum cassia bark compounds and cream containing cassia oil to Aedes aegypti (Diptera: Culicidae) under laboratory and indoor conditions. Pest Manag Sci 2006; 62: 1032-1038

185 Traboulsi AF, El-Haj S, Tueni M, Taoubi K, Nader NA, Mrad A. Repellency and toxicity of aromatic plant extracts against the mosquito $C x$. pipiens molestus (Diptera: Culicidae). Pest Manag Sci 2005; 61: 597-604

186 Beboukian RH, Weldon PJ. Spatial inhibitors, deterrents and repellents for mosquitoes and midges. World Patent 2007025197; 2007

187 Sugimoto $M$. Mosquito repellents of plant origin. Japanese Patent 2004210756; 2004 
188 Hao H, Wei J, Dai J, Dui J. Host-seeking and blood-feeding behavior of Aedes albopictus (Diptera: Culicidae) exposed to vapors of geraniol, citral, citronellal, eugenol, or anisaldehyde. J Med Entomol 2008; 45: 533-539

189 Gu H-J, Cheng S-S, Lin C-Y, Huang C-G, Chen W-J, Chang S-T. Repellency of essential oils of Cryptomeria japonica (Pinaceae) against adults of the mosquitoes Aedes aegypti and Aedes albopictus (Diptera: Culicidae). J Agric Food Chem 2009; 57: 11127-11133

190 Coats JR, Peterson CJ, Zhu J, Baker TC, Nemetz LT. Biorational terpenoid arthropod repellents obtained from plants. US Patent 6524605; 2003

191 Gladkikh SG. Repellents for arthropod carriers of infectious diseases. Zhurnal Mikrobiologii Epidemiologii i Immunobiologii 1953; 11: 6165

192 Blagoveshchenskii DI, Bregetova NG, Monchadskii AS. New deterrent substances for protecting man against the attacks of mosquitoes. Bull Acad Sci USSR, Div Chem Sci (Engl. Transl.) 1943; 40: 119-122

193 Cantrell CL, Klun JA, Bryson CT, Kobaisy M, Duke SO. Isolation and identification of mosquito bite deterrent terpenoids from leaves of American (Callicarpa americana) and Japanese (Callicarpa japonica) beautyberry. J Agric Food Chem 2005; 53: 5948-5953

194 Kim SI, Yeon SH, Yoon HS, Ahn YJ. Natural repellent containing essential oils derived from Zanthoxylum armatum and/or Zanthoxylum piperitum. Korean Patent 955344; 2010

195 Kim GH, Kang SH. Mosquito-repellent composition. Korean Patent 756397; 2007

196 Darling ST. Mosquito repellent composition for skin. World Patent 2007082306; 2007
197 Georges PS. Material controllingly releasing a liquid active substance by evaporation and a mosquito repellent bracelet comprising said material. World Patent 2007026082; 2007

198 Thanispong K, Achee NL, Grieco JP, Bangs MJ, Suwonkerd W, Prabaripai $A$, Chauhan KR, Chareonviriyaphap R. A high throughput screening system for determining the three actions of insecticides against Aedes aegypti (Diptera: Culicidae) populations in Thailand. J Med Entomol 2010; 47: 833-841

199 Hwang YS, Schultz GW, Mulla MS. Structure-activity relationships of unsaturated fatty acids as mosquito ovipositional repellents. J Chem Ecol 1984; 10: 145-151

200 Nataraj S. Mosquito repellent comprising natural oils, turmeric powder, and camphor. Indian Patent 2003MA00347; 2005

201 Lee YI. Natural vegetable essential oil composition having sanitary insect pest exterminating and antibacterial effects and formulation thereof. Korean Patent 2000072252; 2000

202 Gries R, Campbell C, Khaskin G, Avelino N, Gries G. Allyl sulfide compounds, and compositions and methods using said compounds for repelling blood-feeding arthropods. World Patent 2008116321; 2008

203 Hallahan DL, Manzer LE. Preparation of dihydronepetalactone as insect repellent. International Patent 2005034626; 2005

204 Ravid U, Putievsky E, Katzir I, Ikan R. Determination of the enantiomeric composition of terpinen-4-ol in essential oils using a permethylated $\beta$-cyclodextrin coated chiral capillary column. Flav Fragr J 1992; 7: 49-52 